\title{
Bondholder Coercion: The Problem of Constrained Choice in Debt Tender Offers and Recapitalizations
}

\author{
John C. Coffee, Jr. $\dagger$ and William A. Klein $\dagger \dagger$
}

The past decade saw the flourishing of risky, high-yield corporate debt, often called "junk" bonds." Too many companies took on too much debt, and the chickens are now coming home to roost as these bonds have begun to default with increasing frequency. ${ }^{2}$

$\dagger$ Adolf A. Berle Professor of Law, Columbia Law School.

†† Professor of Law, UCLA Law School.

We are grateful for useful insights and information to Richard S. Wilson of Fitch Investors Service, Inc., to Gregory Smith of Indepth Data, Inc., and to Salomon Brothers for data on high-yield debt restructurings. We are also indebted, for their helpful comments, to Alison G. Anderson, Ronald Gilson, J. Mark Ramseyer, Mark Roe, Richard H. Sander, and William D. Warren.

${ }^{3}$ See Securities and Exchenge Commission, Recent Developments in the High Yield Market 14-15 (1990) (staff report) ("SEC Report"); General Accounting Office, Financial Markets: Issuers, Purchasers, and Purposes of High Yield, Non-Investment Grade Bonds (Feb, 1988).

2 The rate of defaults on junk bonds is increasing rapidly. The latest data show that corporations defaulted or missed scheduled payments on $\$ 8.2$ billion of debt, a record level, during the first quarter of 1991, according to Moody's Investors Services, Inc. See Constance Mitchell and Anitz Raghavan, Junk Bond Prices Hold Steady Despite Report That Defaults Hit a Record in the Latest Period, Wall St J C17 (Apr 9, 1991).

In 1988, according to data assembled by Salomon Brothers, $\$ 2.5$ billion in principal amount of junk bonds defaulted; in 1989, $\$ 8.8$ billion defaulted; and, during the first nine months of 1990, $\$ 10.8$ billion defaulted. See Anne Schwimmer, Hard Truths About the Restructuring Business, Investment Dealers' Digest 18 (Nov 26, 1990). One expert has esti- 
The magnitude of the problem is potentially enormous; by one estimate, $\$ 318$ billion of debt has either defaulted already or trades at yields indicating the market's skepticism that it will be repaid on maturity. ${ }^{3}$

Facing the prospect of default, corporate issuers are seeking to restructure or recapitalize their financial structures at a correspondingly increased pace. The market force driving much of this restructuring is the tendency for debt securities of troubled companies to trade in the secondary market at a fraction of their face amount. Thus the issuer can repurchase these securities (or exchange new securities for them) at levels sometimes as low as twenty-five to thirty percent of their face amount. ${ }^{5}$

mated that the amount of publicly held assets in bankruptcy rose from $\$ 5$ billion in 1985 to $\$ 72$ billion in 1989. See Jonathan Peterson, The Bankruptcy Boom, LA Times DI (June 3, 1990) (quoting George Putnam III, publisher of Bankruptcy Data Source).

Default on high-yield debt has correspondingly increased. See SEC Report at 55 (cited in note 1). At least until recently, despite a high default rate on high-yield debt, the interest rate may have been sufficient to compensate for the defaults. See Marshall E. Blume, Donald B. Keim, and Sandeep A. Patel, Returns and Volatility of Low-Grade Bonds, 1977-1989, $46 \mathrm{~J}$ Fin 49, 71 (1991) (finding "no evidence that low-grade bonds are significantly over- or underpriced"); Bradford Cornell and Kevin Green, The Investment Performance of Lowgrade Bond Funds, $46 \mathrm{~J}$ Fin 29, 47 (1991) (finding that, after taking account of risk, "lowgrade bonds are fairly priced relative to high-grade bonds"); Edward I. Altman, Measuring Corporate Bond Mortality and Performance, $44 \mathrm{~J}$ Fin 909, 920 (1989) (finding that "investors have been more than satisfactorily compensated for investing in high-risk securities"); Paul Asquith, David W. Mullins, Jr., and Eric D. Wolff, Original Issue High Yield Bonds: Aging Analyses of Defaults, Exchanges, and Calls, $44 \mathrm{~J}$ Fin 923, 943-44 (1989) (reporting high rates of default, but offering no conclusions about returns). See also Fred R. Bleakley, Many Firms Find Debt They Piled On in 1980s Is a Cruel Taskmaster, Wall St J A1 (Oct 9, 1990).

3 See Alison Leigh Cowan, Bottom Fishing With R. D. Smith, NY Times D1, D3 (Mar 29,1991 ) (quoting estimate of Edward Altman, a finance professor at New York University, that " $\$ 318$ billion worth of marked-down debt . . . has either defaulted or yields 10 percentage points or more than comparable Government securities").

4 In 1990, at least 54 companies attempted or completed recapitalizations "to keep from crashing under the weight of overleveraged capital structures ... . These companies alone carried nearly $\$ 16$ billion in junk bond debt." Laura Jereski and Jason Zweig, Step Right Up, Folks, Forbes 74 (Mar 4, 1991). According to a survey by Salomon Brothers, corporate issuers announced 31 exchange offers (involving $\$ 11.7$ billion in high-yield securities) and 23 tender offers (involving $\$ 4.3$ billion) during 1990 for their own debt securities. Corporate issuers also completed 15 exchange offers and 16 tender offers during 1990, retiring more than $\$ 3.8$ billion in principal amount of high-yield debt and accepting for exchange over $\$ 3.8$ billion in additional debt. See Salomon Brothers, High Yield Restructurings-1990 Summary (Jan 28, 1991) ("Salomon Brothers Study") (on file with U Chi L Rev).

- For example, Southland's Junior Subordinated Debentures traded at only $7 \%$ of face amount before the announcement of that company's offer to repurchase; CNI offered to repurchase its Subordinated Discount Debentures at $25 \%$ of their face amount (which, after taking original issue discount into account, amounted to $28 \%$ of accredited book value); and Greyhound offered to repurchase its $121 / 2 \%$ Senior Subordinated Notes for cash at $271 \frac{1}{2} \%$ of face amount. See Note, Debt Tender Offer Techniques and the Problem of Coercion, 91 
Because distressed debt securities can be repurchased at a significant discount off their face amount, a corporate issuer that is experiencing difficulty in servicing its debt or that realizes it cannot repay the principal on maturity has essentially three options by which it can preserve economic value for its shareholders. First, the issuer can make a tender offer-either a cash offer or an "exchange offer" - at a price somewhat over the trading price, but well below the face amount, of the outstanding debt securities. Second, without making a tender offer, the issuer can repurchase (either in the market or in private negotiations) sufficient debt securities to enable it to pay off the remaining debtholders in the class on maturity. The issuer may make such purchases at widely varying prices or on specially tailored terms that reflect the negotiating position of the particular holder, and may not afford all holders the opportunity to sell..$^{7}$ Finally, the issuer can seek approval of a "prepackaged" plan of reorganization under the Bankruptcy Code. Under such a plan, bondholders would approve a mandatory exchange of securities at or before the time the bankruptcy petition is filed..$^{8}$ The advantage of such "prepackaged bankruptcies" is

Colum L Rev 846, 849 nn 19-20 (1991). Recently, R. H. Macy \& Company, the retailer, spent $\$ 117$ million repurchasing its own bonds. The $\$ 117$ million price was only $42 \%$ of the bonds' $\$ 276$ million book value. See Floyd Norris, Macy Profit Tied to Bond Repurchases, NY Times D1 (Mar 19, 1991).

- This term refers to an exchange of one security for another. Exchange offers may include an offer of a debt or equity security, or a package of such securities, possibly with cash or warrants also, for the outstanding class of debt security.

For general overviews of the use of exchange offers to restructure corporate debt, see Patricia A. Vlahakis, Deleveraging-A Search for Rules in a Financial Free-for-All, in Arnold W. Sametz, ed, Institutional Investing: The Challenges and Responsibilities of the 21st Century 468-98 (Business One Irwin, 1991); Robert E. Spatt and Benedict Tai, Restructuring Public Debt of Highly Leveraged Entities, 6 M\&A and Corp Governance L Rptr 699 (1991); Nicholas P. Saggese, Gregg A. Noel, and Michael E. Mohr, A Practitioner's Guide to Exchange Offers and Consent Solicitations, 24 Loyola LA L Rev 527 (1991); Note, 91 Colum L Rev 846 (cited in note 5); Note, Distress-Contingent Convertible Bonds: $A$ Proposed Solution to the Excess Debt Problem, 104 Harv L Rev 1857 (1991).

7 The corporate issuer does not always initiate these negotiations. Often, certain large institutional investors, known as "vulture funds," will "quietly accumulate positions in distressed companies' bonds and agree to sell those bonds back to the company for a profit, but still much lower than par." Anne Schwimmer, Vulture Funds Add to Workout Complexity, 3 Mergers \& Acquisitions Rptr 2 (No 50, Dec 17, 1990). For a more complete discussion of vulture funds, see text accompanying notes 23-25.

- See 11 USC $\S 1126$ (b) (1988) (permitting a binding vote prior to the filing of the petition in bankruptcy). See Leigh Henry, Prepackaged Bankruptcy Works for Those With Money and Vision, 5 Turnarounds \& Workouts 1 (No 2, Feb 1, 1991); Richard D. Hylton, Prepackaging a Bankruptcy, NY Times C2 (Nov 26, 1990).

For overviews of the tactical and legal issues surrounding "prepackaged bankruptcies," see John J. Huber, Bryan B. Edwards, and Jeffrey C. Soza, Restructuring High-Yield Securities Through Prepackaged Bankruptcies, 5 Insights 3 (No 5, May 1991); Stephen Case 
that, if the requisite majority of "two thirds in amount and more than one-half in number of the allowed claims"9 consents, then the exchange offer-restyled as a reorganization plan-binds the minority as well. In short, there can be no holdouts. This last technique is becoming more popular. ${ }^{10}$

The corporate issuer often employs these three techniques, not in isolation, but in sequence. Usually, the issuer will make an exchange offer to the holders, and then may privately negotiate with holders who have not tendered." Finally, if it cannot obtain the percentage it desires, the issuer may terminate its tender offer and turn to a prepackaged bankruptcy plan, in effect seeking a mandatory exchange on terms similar to the prior voluntary exchange. ${ }^{12}$ The common backdrop to the issuer's efforts to restruc-

and Mitchell Harwood, Current Issues in Prepackaged Chapter 11 Plans of Reorganization and Using the Federal Declaratory Judgment Act for Instant Reorganizations (unpublished paper prepared for Bankruptcy Law Symposium sponsored by the New York University of Law, the Annual Survey of American Law, and the John J. Galgay Fellowship Program, Apr. 12, 1991) (on file with U Chi L Rev). For further discussion of prepackaged bankruptcies, see text accompanying notes 113-28.

- See 11 USC \& 1126 (c) (1988).

10 See Salomon Brothers Study at 1 (cited in note 4) ("The number of issuers seeking bondhoider approval of prepackaged bankruptcy reorganization plans concurrent with distressed exchange offers is growing."). During 1990, Interco, Inc., Tracor Inc., The Southland Corp., and JPS Textile Group, Inc. turned to prepackaged bankruptcy plans after failing to obtain bondholder approval of an exchange offer. See id at $8,11,13$. In late 1990, Trump Taj Mahal Funding Inc., a part of Donald Trump's financial empire, and Price Communications Corp. also made exchange offers as part of a prepackaged bankruptcy plan. Id at 4 .

But another study has concluded that "[i]n practice, successful prepackaged filings are extremely rare." Stuart C. Gilson, Kose John, and Larry H. P. Lang, Troubled Debt Restructurings: An Empirical Study of Private Reorganization of Firms in Default, $27 \mathrm{~J}$ Fin Econ 315, 325 (1990). This study observed that, in a sample of 80 firms that restructured debt outside of bankruptcy in 1978 through 1987, "publicly traded debt is always restructured through exchange offers." Id at 323 . We believe these studies differ because of timing: prepackaged bankruptcies emerged as a viable option for debt restructuring in 1990.

${ }_{11}$ A variation on this pattern is to terminate the exchange offer, return all the tendered debt securities, and then begin private negotiations. During 1990, International Controls Corp. did this after failing to obtain the $80 \%$ in principal amount of each issue it had sought. It announced vaguely that it would purchase the debentures either in the open market or in private transactions. Salomon Brothers Study at 10 (cited in note 4). Similarly, G-I Holdings Inc. turned to private purchases after its exchange offer expired. Id at 9. In another more extreme variation, Michelin Finance terminated its cash tender offer in 1990 for the notes of its subsidiary, Uniroyal Goodrich Tire. Michelin "declined to negotiate with an adversarial bondholder group ... [and] filed to deregister the bonds from filing requirements with the SEC." Id at 15.

12 The Southland Corporation, Tracor Corp., Interco, Inc., and JPS Textile Group, Inc. all followed this sequence during 1990 . See note 116. For the full account of the involved negotiations at Southland, see In re Southland Corporation, 124 Bankr 211 (Bankr N D Tex 1991). Similarly, Republic Health Company turned to a prepackaged plan after two years of negotiation with and among its creditors proved unsuccessful. See Henry, 5 Turnarounds \& Workouts at 2 (cited in note 8). 
ture its creditors' claims is the likelihood that a prolonged bankruptcy proceeding will harm all the participants. In fact, only one in ten companies that file for Chapter 11 protection successfully emerges with a confirmed plan of reorganization. ${ }^{13}$ In the view of the professionals in this field, the cost and delay of bankruptcy - the high legal and administrative expenses, the disruption of business planning, and the possibility of losing customers and suppliers during this uncertain interim-make avoiding bankruptcy (except on a "prepackaged" basis) the common goal of all creditors. ${ }^{14}$

Attempts by issuers to reduce and restructure their debt by exchanging new securities for outstanding securities are not legally objectionable, and indeed are socially desirable to the extent that they spare society the deadweight loss of bankruptcy costs. But the use of coercive means that threaten bondholders with being made worse off if they decline the exchange does raise serious legal issues. Corporate issuers may coerce such exchanges in one of two ways: First, creditors report that the debtor corporation often manipulates the threat of bankruptcy to force the debtholders to accept its proposed exchange. ${ }^{15}$ Second, issuers may seek to amend the indenture under which the bonds were issued either to strip the outstanding bonds of their protective covenants or to subordinate them to the new class of debt securities exchanged for

${ }^{13}$ Henry, 5 Turnarounds \& Workouts at 2 (cited in note 8) (citing study by Administrative Office of the United States Courts). The odds are, however, much better for "prepackaged" plans. Id.

${ }^{14}$ See Sharon Reier, Bankruptcy Boondoggle, Fin World 36, 38 (Oct 16, 1990). See also Mark M. Jaffe, Chapter 11 Strategies and Techniques-Creditors Committees, Effective Use of Plan Provisions, Objections to Confirmation, Financing a Chapter 11 Case, "Cramdown" and How It Works, 59 Tulane L Rev 1298, 1306 (1985).

We believe that bankruptcy costs are substantial, particularly for those issuers whose bondholders have accepted coercive exchange offers. In these cases, high bankruptcy costs do arm the issuer with substantial leverage, by which the issuer can negotiate a pre-bankruptcy reduction in its indebtedness that still leaves the shareholders owning substantial equity in the corporation. We appreciate that the academic literature has long debated the size and significance of bankruptcy costs. See notes 43-46.

${ }^{15}$ Wilbur Ross of Rothschild Co., probably the best known bankruptcy adviser among investment bankers, observes:

A lot of games are played with Chapter 11. A lot of issuers deliberately set up a period where they go into default. Sometimes, companies threaten bankruptcy. Then the companies paint a picture of gloom and doom of what will happen. What usually happens is that the company no longer pays interest on unsecured debt and that saves it cash at the bondholders' expense.

Reier, Fin World at 38 (cited in note 14). 
them. ${ }^{16}$ Both techniques have the same aim: to induce bondholders to accept an exchange that they would otherwise refuse. In this Article, we will principally address the legitimacy of the second technique, but many of our conclusions apply to the first as well.

Ultimately, in this Article, we will argue that the problem of bondholder coercion involves more than simply extortion by the issuer: coercion can be good or bad, depending on the circumstances. But, in Parts I and II, we start by demonstrating how issuers frequently use the threat of bankruptcy or adverse indenture amendments to force creditors to accept an unfavorable recapitalization, which allows shareholders to continue to own a significant portion of the firm's equity even though the firm has not met its obligations to its creditors. ${ }^{17}$ Specifically, we demonstrate that, by exploiting the threat that bondholders will be made worse off, corporations can achieve favorable recapitalizations through exchange offers that put the bondholders into a kind of prisoner's dilemma, thereby coercing the bondholders to accept an amendment to their indenture that in their unconstrained choice they would reject.

These threats thus render at least partially obsolete the simple notion that equity is subordinate to debt. ${ }^{18}$ Indeed, the disclosure

16 The Salomon Brothers Study of all 1990 high-yield restructurings counts 26 completed or abandoned transactions and five pending transactions in which issuers sought a bondholder vote to amend the indenture under which their bonds were issued. Salomon Brothers Study (cited in note 4).

17 Bankruptcy also raises a moral hazard problem. Shareholders may change the business and financial policy of the firm to take long-shot risks that, if successful, will avert insolvency. We do not focus on these possible problems, but only on the gaming behavior that the issuer's management may adopt in proposing a recapitalization. Shareholders have no rational interest in proposing an exchange offer or other reorganization that does not leave them some interest in the reconstituted firm (even if the firm is insolvent and they have no strict legal right to such an interest). If bankruptcy threatens bondholders with unnecessary and avoidable losses, it is in the shareholders' interest to exploit this threat to obtain at least a small share of the reorganized firm.

${ }_{18}$ Commentators generally agree that equityholders typically receive some value in bankruptcy even when senior claimants are not fully compensated. But they disagree over the magnitude of this problem. Some argue that "pro-debtor bankruptcy judges are violating creditor contracts." Lawrence A. Weiss, Beware the Bankruptcy Judges, NY Times F11 (Apr 28, 1991). But an important recent empirical study concludes that this view exaggerates the amount received by the equityholders and the difficulty of resisting their demands. See Lynn M. LoPucki and William C. Whitford, Bargaining Over Equity's Share in the Bankruptcy Reorganization of Large, Publicly Held Companies, 139 U Pa L Rev 125 (1990).

One empirical study finds that the amount paid to shareholders in excess of what they would have received under the absolute priority rule was on average $7.6 \%$ of the total value paid. See Allan C. Eberhart, William T. Moore, and Rodney L. Roenfeld, Security Pricing and Deviations from the Absolute Priority Rule in Bankruptcy Proceedings, $45 \mathrm{~J}$ Fin 1457, 1458 (1990). See also Lawrence A. Weiss, Bankruptcy Resolution: Direct Costs and Violation of Priority of Claims, $27 \mathrm{~J}$ Fin Econ 285, 299 (1990) (strict priority of claims is violated in $\mathbf{7 8 \%}$ of the cases studied). 
requirements of the federal securities laws actually enhance these threats: The offering documents used by the issuer often contain a "liquidation analysis" that compares what bondholders would receive in bankruptcy to the corporation's offer. Such disclosures usually suggest that the bondholder will be significantly worse off if the corporation withdraws the offer and enters bankruptcy. ${ }^{19}$ This spectacle of the corporation threatening to "welch" on its debts may account for the highly skeptical reception that issuer debt tender offers have received in the financial press. ${ }^{20}$

Nevertheless, as we indicated above, it oversimplifies to treat bondholder coercion as simply extortion by the corporate issuer. Indeed, an exclusive focus on the corporate issuer misses half the story. We have seen that rational bondholders should be willing to scale down their claims in order to avoid the high costs and uncertainty of bankruptcy. Yet, they in fact have great difficulty in achieving out-of-court consensual restructurings. ${ }^{21}$ In particular, exchange offers made by a distressed issuer to its bondholders regularly fail..$^{22}$ The evidence then seems to present a paradox: By all accounts, bondholders fear bankruptcy and want to achieve a consensual scaling down of their claims that avoids its high costs and uncertainty. Yet, they in fact have great difficulty in achieving this goal.

\footnotetext{
10 See Note, 91 Colum L Rev at 850 (cited in note 5), for a review of offering materials in several recent tender offers. For example, the Southland Proxy Statement and Prospectus, dated October 5, 1990, estimated that most bondholders would receive nothing in liquidation, except for one class of senior noteholders that would receive $39 \%$ of face amount. Id at $850 \mathrm{n}$ 23. In the Bond Brewing Holdings, Ltd. tender offer, the Offer to Purchase and Consent Solicitation estimated that bondholders would eventually receive between $25 \%$ and $37 \%$ of face amount if the company entered bankruptcy, as compared to the immediate tender price of $40 \%$ of face amount. Id at 850 .

so See, for example, Benjamin J. Stein, Insult to Injury: Junk Holders Get Offers They Should, But Can't Refuse, Barron's 42 (May 28, 1990); Matthew Schifrin, Enough Already!, Forbes 126 (May 28, 1990).

21 As of late 1990, "only two out-of-court restructurings of distressed, highly leveraged companies had actually been accomplished." Schwimmer, Investment Dealers' Digest at 20 (cited in note 2). This conclusion may overstate the evidence somewhat. During 1990, Insilco, International Controls, Interco, JPS Textile, and Southland were all unsuccessful in their attempted exchange offers when bondholders did not tender the minimum amounts they required. Salomon Brothers Study at 1 (cited in note 4). Figure 4 to the Salomon Brothers Study shows that at least 11 other exchange offers were terminated during 1990. Id at 8-18. But even if 16 offers failed, another 31 exchange offers and 23 tender offers were successfully completed during 1990 (although not all were necessarily made by "distressed, highly leveraged companies"). Id.

12 See Schwimmer, Investment Dealers' Digest at 20 (cited in note 2) ("Indeed, exchange offers are failing with increased frequency as bondholders refuse to settle at the offered terms."). See also data cited in note 27.
} 
In Part III, we explain this seeming paradox by identifying a new player on the financial scene: the vulture fund. Vulture funds are institutional investors that invest in distressed bonds, buying them at a fraction of their face amount in anticipation of a restructuring. ${ }^{23}$ Such investors often aim for a thirty percent profit or more on a short-term investment. More significantly, vulture funds are inclined to hold out for disproportionate repayment of the bonds that they purchased at a marked discount. By holding out, vulture funds may succeed in being repaid in full at maturity. In so doing, however, they impede the ability of the majority of the bondholders to achieve a consensual scaling down of the debtor corporation's over-leveraged capital structure that demands a pro rata sacrifice by each bondholder to avoid the greater losses incident to bankruptcy. ${ }^{24}$ Both the corporate debtor and the other bondholders realize that if a significant percentage of the debtholders spurn the proposed recapitalization then any savings realized by the corporation will simply go on maturity to pay off the claims of these holdouts. At present, there is reason to believe that if as few as five to ten percent of the bondholders hold out, they will soak up the gains from the consensual scaling down by their fellow creditors. ${ }^{25}$

23 For recent accounts of the vulture fund, see Schwimmer, 3 Mergers \& Acquisitions Rptr 2 (cited in note 7); David Carey, Bankruptcy Buzzards, Fin World 60 (Jan 22, 1991); John Egan, Vulture Play, Fin World 41 (Mar 19, 1991); Matthew Schifrin, Pay Up ... or Else, Forbes 74 (Aug 6, 1990). Increasingly, vulture funds are mutual funds. See Carey, Fin World at 60-61.

Three of the leading players in the "vulture fund" field are Martin Whitman of Whitman, Heffernan \& Rhein (which now manages two mutual funds), see Carey, Fin World at 61; Randall Smith of R. D. Smith \& Co., see Cowan, NY Times at D6 (cited in note 3); and Stanford Phelps. In particular, Mr. Phelps's much publicized actions-buying high-yield debt at prices equivalent to $10 \%$ of the security's face amount and then holding out, even when $95 \%$ of the other bondholders accept management's proposed recapitalization-have given rise to the phrase "bondmail." See Stacy Soltis, Bondholder Stan Phelps Finds Muscling Debtors Can Only Get You So Far, 4 Turnarounds \& Workouts 1, 2 (No 15, Oct 1, 1990); Matthew Schifrin, Sellers Beware, Forbes 36 (Jan 21, 1991).

24 For an earlier article recognizing that avoiding bankruptcy by scaling down the corporation's debts is desirable, see Mark J. Roe, The Voting Prohibition in Bond Workouts, 97 Yale L J 232 (1987). For an overview of how such a contractual solution can be achieved, see Howard J. Kashner, Majority Clauses and Non-Bankruptcy Corporate Reorganizations-Contractual and Statutory Alternatives, 44 Bus Law 123 (1988).

28 The fact that most issuers now specify minimum tender conditions of $90 \%$ to $95 \%$ (before they are obligated to accept tendered bonds) is evidence of their view that a higher holdout rate destroys the value of the recapitalization to them. To illustrate, assume that Debtor Corp. has $\$ 1$ billion in junk bonds outstanding, which will mature in two years, but which its management realizes Debtor cannot repay. Assume its bonds are trading at $50 \%$ of their face amount, which price partly reflects the expected additional losses to bondholders if the firm were to enter bankruptcy. 
Recognizing this danger, both the corporate debtor and the other bondholders typically respond ex ante by insisting that the exchange offer be conditioned on some high minimum tender level-usually, ninety or ninety-five percent. ${ }^{28}$ For example, the offer may state that the issuer may terminate it if less than ninetyfive percent of the principal amount of the outstanding bonds are tendered. This condition not only protects shareholders and the majority of the bondholders, but also explains why such offers frequently fail: The high minimum tender condition frequently cannot be satisfied, particularly when vulture fund investors have acquired their interest in order to hold out for special treatment.

Believing that Debtor cannot possibly pay more than $\$ 700$ million when these bonds mature, management proposes to exchange a package of securities having an expected value of $\$ 650$ million (thus preserving a small $\$ 50$ million "stub" value for its shareholders) for the outstanding bonds worth $\$ 1$ billion. This $\$ 650$ million offer is a $\$ 150$ million premium over the market value of $\$ 500$ million. But the vulture fund investors may still hold out, believing that the firm can pay their claims in full on maturity if most of the other bondholders exchange their bonds pursuant to the firm's offer.

Suppose then that $85 \%$ of the bondholders tender and $15 \%$ hold out. The tendering bondholders receive a package of securities equal to $\$ 552.5$ million ( $85 \%$ of $\$ 650$ million), but the holdouts remain entitled to $\$ 150$ million ( $15 \%$ of $\$ 1$ billion). As a result, the total debt claims ( $\$ 552.5$ million plus $\$ 150$ million) against the firm exceed $\$ 702$ million. (Remember that the Debtor could not repay more than $\$ 700$ million). The recapitalization has thus failed to scale down Debtor's debt to a manageable level, and the holdouts have effectively seized the small stub equity value. Put simply, the holdouts have soaked up the gains from the consensual scaling down. If Debtor were to consummate this exchange offer, it would not only extinguish the value of the equity held by its own stockholders, but it would also simply transfer wealth from the majority of the bondholders that tendered to the minority that held out.

Let us explain some of the assumptions in this example. First, we assumed that the bonds were trading below their actual value-i.e., the value of Debtor if Debtor were to apply all of its cash flow and liquidate all of its assets in order to fund their repayment. Debtor could pay $\$ 700$ million, but the market "prices" the bonds at only $\$ 500$ million.

There are three explanations for this discount of $\$ 200$ million: First, management may have non-public information, so that management can better estimate Debtor's ability to repay on the bonds' maturity. Rationally, management might not release such information, because it wants the bonds to trade at a discount in order to economize on their repurchase. Second, the market for distressed debt securities may be inefficient. This is certainly the popular impression. See note 30 and accompanying text. Finally, even if the secondary debt market is efficient, the market price may be accurately discounting the likely loss in the bonds' value due to bankruptcy costs (if the firm files a Chapter 11 petition), or to opportunistic behavior by management, such as delaying the reorganization in order to secure greater compensation for shareholders. For a discussion of bankruptcy costs, see text accompanying notes $43-47$.

20 Unless it binds itself not to, the corporation can waive this minimum tender condition. However, bondholders have sometimes demanded that the condition be non-waivable in order to protect tendering bondholders from holdouts. See In re Southland Corporation, 124 Bankr at 126 (bondholders steering committee insisted on non-waivable $95 \%$ tender condition to prevent "windfall" to non-tendering bondholders). In fact, the Salomon Brothers Study notes that a $90 \%$ to $95 \%$ minimum tender condition has now become "typical." Salomon Brothers Study at 1 (cited in note 4). 
The bottom line, then, is that the bondholder's problem is two-sided: The bondholder must fear both the issuer's threats and its fellow bondholders' opportunism. In this light, coercion can be either good or bad. On the one hand, as we have already noted, coercion may allow the issuer (and, by extension, its stockholders) to "welch" on its indebtedness. On the other hand, the holdout problem may justify some coercion in order to prevent the minority from frustrating the majority's interest in achieving a necessary scaling down of the corporation's debt in a way that taxes all bondholders evenly. Today, corporate issuers prefer to threaten potential holdouts by conditioning their exchange offer on a requirement that a majority of the bondholders vote, at or before the time they tender into the issuer's offer, to amend the indenture to eliminate all or most of its protective covenants. ${ }^{27}$ This "stripping" of the covenants makes the bonds a less attractive investment to those who would otherwise hold out, and thus it may induce them to accept the exchange offer.

This two-sided nature to the problem of coercion may explain the current division among commentators. Some view debt tender offers in sanguine terms as a rational effort by sophisticated bondholders to take collective action. ${ }^{28}$ Others characterize debt tender offers as sinister attempts by corporations to coerce their bondholders into sacrificing their debt claims by threatening to worsen their condition. ${ }^{29}$ It is our position in this Article that both sides in this debate are correct-at least some of the time. Whether bondholder coercion is justified depends on whose decision is being enforced, the technique used, and the degree of organization within the particular group of bondholders. Accordingly, neither public

\footnotetext{
${ }^{27}$ The Salomon Brothers Study shows that at least 26 high-yield restructuring transactions, in which corporate issuers solicited bondholder consents to amend the indenture under which the debt securities were issued, were completed during 1990. Generally, the amendments would eliminate restrictive covenants; in a few cases, they would also subordinate the untendered old securities to the new securities or, in the case of secured debt, would release collateral pledged to support the old securities. See Salomon Brothers Study at 8-18 (cited in note 4). The study lists a total of 53 transactions, although many of these were relatively minor restructurings and may not have involved distressed companies. In addition, 5 other transactions, in which the issuer was seeking bondholder consents as part of a high-yield restructuring, were in progress on December 31, 1990: Banner Industries, Inc., Price Communications Corp., LVI Group, Inc., Service America Corp., and Divi Hotels N.V. Id at 3-6.

${ }^{23}$ See Note, 91 Colum $\mathrm{L}$ Rev at 890 (cited in note 5).

20 See Note, 104 Harv L Rev at 1860-66 (cited in note 6) (recognizing that there are both "holdout" and "hold-up" problems). See also Stein, Barron's at 42 (cited in note 20); Schifrin, Enough Already!, Forbes 126 (cited in note 20).
} 
policy nor private contracting should seek to preclude, in the abstract, all use of "coercive" cash or exchange offers for debt securities. Nor should such techniques be wholly legitimized. Rather, public policy should seek to shift control over the coercive potential from the corporate issuer to a majority of the bondholders. The majority would then be able to discipline an opportunistic minority that is seeking to hold out and receive a disproportionate share of the distressed debtor's assets.

In Part IV, we propose a regime that would accomplish this goal: an exchange offer procedure in which the offer is conditioned on the prior and independent consent of the bondholders of the amendment of the indenture agreement. We will demonstrate that this proposed regime prevents the corporation from subjecting the bondholders to the coercive prisoner's dilemma. We also discuss other alternative means of recapitalization, such as the prepackaged bankruptcy, which can help to solve the holdout problems posed by the vulture funds. Although the prepackaged bankruptcy is only coming into use today, the availability of this less coercive alternative at the very least eliminates any justification for the coercive exchange offers that corporations presently use.

Finally, in Part V, we present different legal theories by which courts and the Securities and Exchange Commission could implement our proposed standard. We also propose model indenture language that would accomplish the same result through private contracting.

\section{Empirical Assumptions About the Debt Market}

Three factors distinguish trading in distressed debt securities from trading in equity securities. First, most observers have described the secondary market in debt securities as an inefficient market: volatile price swings are common, information is scarce, and liquidity is often lacking. ${ }^{30}$ Second, substantial bankruptcy costs are risked if the corporation enters reorganization. As a re-

\footnotetext{
so For example, one New York Times reporter, after interviewing key traders and participants in this market, described the debt market as follows:

The market ... is by any definition an inefficient and underregulated backwater of the securities business. Information is scarce, securities practically trade by appointment, and brokers charge as much as 2 percent of the trade for lining up the buyer and seller, or for keeping a risky, illiquid security in inventory.

Cowan, NY Times at D6 (cited in note 3). For a similar description, see Diana B. Henriques, Playing the Bankruptcy "Endgame", NY Times F15 (Sep 23, 1990). Others suggest that "trading on inside information is apparently rampant" in this area. Schifrin, Sellers Beware, Forbes at 36 (cited in note 23).
} 
sult, the success or failure of pre-bankruptcy negotiations can significantly affect the value of the bondholders' securities. Third, bondholders, more so than stockholders, can often organize to take collective action.

\section{A. Market Inefficiency and Asymmetric Information}

Our belief in the inefficiency of the high-yield debt market follows from both the absence of regular trading and the scarcity of information. First, there is simply not a liquid auction market, or even continuous trading, in debt securities, at least not of the kind that is available for equity securities of the same issuers. ${ }^{31}$ Hence, most trading is in private negotiations, and other bondholders are not necessarily aware of recent prices or trading information.

Second, information about debt securities is often inadequate. Information often reaches public bondholders considerably later than it reaches bank creditors and others who deal with corporate management on a continuing basis. ${ }^{32}$ Corporations in bankruptcy may cease to file, or become delinquent in filing, periodic information with the Securities and Exchange Commission (SEC). Moreover, current law does not require an issuer to continue to file periodic information with the SEC if it has neither a security listed on a national securities exchange nor a class of equity security held by 300 or more persons. ${ }^{33}$ As a result of leveraged buyouts, many formerly public corporations are able to deregister with the SEC, even though their bonds remain outstanding. Thereafter, these corporations provide only the minimal information required by the bond

${ }^{31}$ While the daily trading volume of bonds is more than double that of common stock, the New York Stock Exchange "handled only $0.2 \%$ of the daily turnover." J. Edmund Colloton, Bondholder Communications-The Missing Link in High Yield Debt 18 (Report for Hill and Knowlton, Inc., 1990). The market for high-yield debt has also been particularly thin since the collapse of Drexel Burnham Lambert in 1989. See Anise C. Wallace, "Junk Bond" Dealers Are Betting on a New, Slimmer Market, NY Times F12 (Apr 1, 1990).

s2 For such a view by an experienced investment officer at one of the largest institutional investors (TIAA/CREF), see Sharon F. Manewitz, The Corporate Bondholder in Workouts and Bankruptcies, in Sametz, ed, Institutional Investing 499, 502 (cited in note 6) ("In most instances, public bondholders are unaware of the early stages of a workout. Generally, the first to be in a position to recognize that a problem exists or is about to occur are the company's bank lenders.").

ss Under $\S 12(\mathrm{~g})(1)$ of the Securities Exchange Act of 1934, an issuer must enter the SEC's periodic reporting system and file the reports mandated by $\S 13$ of that Act once it has more than 500 shareholders of record. However, the issuer may deregister under $\S 12(\mathrm{~g})(4)$ once the number of holders of record of this class falls below 300 . If the bonds are listed on a national securities exchange, $\S 12(b)$ will require periodic information until the issuer takes the bonds off the list. 
indenture. ${ }^{34}$ A recent Wall Street Journal survey found that bonds that are not exchange-listed may be simultaneously traded at very different prices by different brokerage firms ${ }^{35}$ - the result one would expect from a market characterized by irregular trading and little publicly available information.

Most importantly, the securities analyst-the intermediary whom many observers see as the principal mechanism of capital market efficiency-simply plays less of a role in the market for distressed debt. ${ }^{36}$ Relatively few firms research distressed securities because consumer demand is small: typically only specialized firms with a taste for risky investments trade in such securities. As a result, the spread between bid and asked prices-one measure of a market's efficiency-is often much wider for distressed debt than for other securities. ${ }^{37}$ One debt rating service publishes a list of debt securities whose investment value is, in the judgment of the service, significantly above their trading value (sometimes by thirty percent or more). ${ }^{38}$ When market and investment value deviate this much, it is difficult to call such a market efficient.

Ultimately, however, it is not necessary to accept our claim that the market for distressed debt securities is relatively inefficient to conclude that market prices in this market do not necessarily reflect investment value if all material information about the bonds were released. The standard definition of market efficiency is that "prices at any time 'fully reflect' all available informa-

\footnotetext{
34 See Laura Jereski, None of Your Business, Forbes 68 (Apr 29, 1991) (some debtholders complain that "[b]onds are harder to price and trade without public information, and ... some companies take advantage of the lack of information to buy in their bonds in the open market.").

${ }^{36}$ See Laurie P. Cohen, Let the Small Investor Beware Those Junk Bond Prices, Wall St J C1 (Mar 18, 1991) (Prudential and Merrill Lynch simultaneously quoting bid prices of $\$ 95$ and $\$ 88$, respectively, for the same high-yield debt security. However, this survey found that exchange-listed debt securities traded at comparable prices.).

so Proponents of the efficient market hypothesis recognize that the market may be less efficient with respect to forms of new information that are costly to acquire or verify. See Ronald J. Gilson and Reiner H. Kraakman, The Mechanisms of Market Efficiency, 70 Va L Rev 549, 626 \& n 205 (1984), and studies cited therein. They acknowledge that those trading in the market may have insufficient incentive to invest in attempting to value such information. See James H. Bjerring, Josef Lakonishok, and Theo Vermaelen, Stock Prices and Financial Analysts' Recommendations, $38 \mathrm{~J}$ Fin 187 (1983). Such a description fits the market for distressed debt securities, where debt trading is thin to sporadic and the demand for securities analysts' services is correspondingly reduced.

${ }^{37}$ See Henriques, NY Times at F15 (cited in note 30) (noting bid and asked prices of $\$ 40$ and $\$ 60$ for high-yield notes of Taj Mahal Casino). Such wide disparities tend to be short-lived.

ss See Alexandra Ourusoff, The Junketeers, Fin World 64, 66 (Oct 1, 1991) (ratings of Fitch Investors Service Company predicted recovery value with trading price).
} 
tion." ${ }^{39}$ But market prices in any market can seldom "fully reflect" information that the issuer has not publicly released (i.e., "inside information"). As a result, an issuer considering an exchange offer for its distressed debt securities has a perverse incentive to withhold positive information from the market, in order to increase the discount by which the bonds trade below their face amount. The greater the discount, the greater the bargain the issuer gains by repurchasing the bonds-even at a premium over their market price. Indeed, by withholding information, the issuer may convince the market that the degree of financial distress is far worse than it actually is. ${ }^{40}$ Given the usual bias of management toward maximizing the firm's share price, the market may not expect such a tactic, and, in any event, risk-averse, smaller bondholders are ill-equipped to call management's bluff. ${ }^{41}$

In summary, in a world of high price volatility and scarce information, the fact that an issuer's exchange offer is above the current market price carries less assurance that the offered price is "fair" than it would for other securities. ${ }^{42}$

B. The Impact of Bankruptcy Costs on the Value of Debt Securities

The second distinctive feature about the market for distressed debt securities is the magnitude of bankruptcy costs. The trustee will finance the legal and other costs of administering the bank-

${ }^{39} \mathrm{See}$, for example, Gilson and Kraakman, $70 \mathrm{Va} \mathrm{L}$ Rev at 554-55 (cited in note 36) (citing Eugene Fama, Efficient Capital Markets: A Review of Theory and Empirical Work, $25 \mathrm{~J}$ Fin 383 (1970)).

so Then Professor Easterbrook and Professor Fischel argue that when a firm suspends or reduces its information flow "investors always assume the worst. [Corporations] must disclose the bad with the good, lest investors assume that the bad is even worse off than it is." Frank Easterbrook and Daniel Fischel, Mandatory Disclosure and the Protection of Investors, $70 \mathrm{Va} \mathrm{L} \mathrm{Rev} \mathrm{669,} 683$ (1984). We agree with this statement as a generalization that silence implies disaster, but here it creates an easily manipulated tactic by which to depress the bonds' market value. Indeed, once the issuer announces its tender or exchange offer, it can then make full disclosure to avoid antifraud liability. But at this point, any rebound in the bonds' value will appear to be a response to the offer and not a reflection of new information about investment value.

11 Vulture funds may be less susceptible to such a tactic, and this may partially explain their tendency to hold out.

${ }^{42}$ In an efficient market, it is frequently argued that the market price is the best, most reliable estimate of actual value, and an offered price above the market price cannot be "unfair." See, for example, Frank Easterbrook and Daniel Fischel, The Proper Role of a Target Management in Responding to a Tender Offer, 94 Harv L Rev 1161, 1182-90 (1981). But see Saul Levmore, Efficient Markets and Puzzling Intermediaries, 70 Va L Rev 645, 651-57 (1984) (arguing that inframarginal shareholders may place a higher value on the security). 
ruptcy proceeding, and thus will have a senior claim against the bankrupt estate to which the existing creditors will be subordinated. ${ }^{3}$ But the more important cost of bankruptcy may be the adverse effect of uncertainty and judicial control on business planning, customer loyalty, and trade creditors. ${ }^{44}$ Scholars have long debated the magnitude of bankruptcy costs, ${ }^{45}$ but the fairest generalization is that bankruptcy costs differ significantly across industries. In industries where customers or suppliers depend upon the long-term existence of a firm, bankruptcy costs may be high because customers may transfer their loyalties to a competitor, and because suppliers may begin to withhold products or services. ${ }^{46} \mathrm{Fi}$ -

is See 11 USC $\S \S 327(a), 1107$ (1988) (granting authority to trustee and/or debtor in possession to issue certificates to cover administration expenses).

The most recent, and probably the most comprehensive, study of the costs of bankruptcy reports that "on average, direct [administrative] costs of bankruptcy are $3.1 \%$ of the book value of debt plus the market value of equity of the fiscal year end prior to the bankruptcy filing, with a range from $1 \%$ to $6.6 \%$." Weiss, $27 \mathrm{~J}$ Fin Econ at 299 (cited in note 18). Earlier studies also reported modest direct costs. See James S. Ang, Jess H. Chua, and John J. McConnell, The Administrative Costs of Corporate Bankruptcy: A Note, $37 \mathrm{~J}$ Fin 219, 224 (1982) (finding that the median administrative cost is about $2 \%$ of the value of assets); Jerold B. Warner, Bankruptcy Costs: Some Evidence, 32 J Fin 337, 343 (1977) (a study of eleven railroad bankruptcies, finding that direct costs average $5.3 \%$ of the market value of the firm's securities at the date of the fling of the petition).

"Nevins Baxter, a professor of finance, has observed:

Perhaps the most important cost of bankruptcy proceedings is the negative effect that financial embarrassment may have on the stream of net operating earnings of the business firm. The firm may find it very difficult to obtain trade credit, [and] customers may question its reliability and permanence as a source of supply and may choose to deal elsewhere. Questionable financial condition may be equivalent to negative publicity about the integrity of the firm.

Nevins D. Baxter, Leverage, Risk of Ruin and the Cost of Capital, 22 J Fin 395, 399 (1967). 45 See Merton H. Miller, Debt and Taxes, 32 J Fin 261, 262-63 (1977). Miller relied on a study by Professor Jerold Warner, see Warner, $32 \mathrm{~J}$ Fin at 341 (cited in note 43), that tabulated the direct costs of bankruptcy for a sample of eleven railroads that filed bankruptcy petitions between 1930 and 1955. That study estimated that these costs averaged only $5.3 \%$ of the market value of the firm's securities as of the date of the petition's filing. Miller, $32 \mathrm{~J}$ Fin at 262-63. This modest number may be a product of the fact that railroads are a natural monopoly; in any event, it does not include the indirect costs of lost customers and suppliers. Another study of smaller firms found median administrative costs in bankruptcy to be about $2 \%$ of the value of the assets. See Ang, Chua, and McConnell, $37 \mathrm{~J}$ Fin 219 (cited in note 43). Other scholars have claimed that bankruptcy costs cannot be significant because they should be limited by the costs of informal, consensual reorganization. See Robert A. Haugen and Lemma W. Senbet, The Insignificance of Bankruptcy Costs to the Theory of Optimal Capital Structure, 33 J Fin 383 (1978). But, as recent bondholder workouts have shown, informal reorganizations may be difficult to achieve because of the problem of holdouts. Hence, this argument proves little. Moreover, none of these studies responds to more recent research which shows that stockholders obtain a higher percentage of the firm's value than they are entitled to receive under the absolute priority rule. See sources cited in note 18 .

16 For example, customers of a computer manufacturer might feel that it is unsafe to remain dependent on the manufacturer if it enters bankruptcy, because they are uncertain 
nally, legal proceedings are always susceptible to delay, during which the issuer will not pay interest on the debt to the unsecured debtholders. Thus the time value of money causes delay to be more costly to the creditors than to the shareholders, if they participate in the reorganization. ${ }^{47}$ In contrast, a consensual renegotiation of the creditors' claims (whether through an exchange offer or a prepackaged bankruptcy plan) may only take several weeks.

It is therefore realistic to believe that management's threat to file a Chapter 11 petition may induce bondholders to accept an exchange offer that they would decline if it were not backstopped by the prospect of a bankruptcy reorganization as the alternative.

\section{The Potential for Collective Action by Debtholders}

Finally, concentrated ownership of distressed securities suggests that debtholders (much more so than equityholders) may often be able to engage in collective action. Often, high-yield debt securities are sold in private placements to a limited group of institutional purchasers. Even when the offering is a public one, most of the purchasers are sophisticated institutional investors, which are repeat players and interact with each other regularly. Sometimes as few as four institutions may hold the majority of the outstanding class; ${ }^{48}$ other times, however, the number of owners will range between fifty and one hundred, with no small group holding a majority. ${ }^{49}$

\footnotetext{
whether the company can keep pace with the high rate of technological change. In contrast, customers of a railroad might see little reason to switch or might have little ability to do so.

17 While the debtholders lose interest on their money, the equityholders extract what amounts to an option on the firm: the equityholders generally lose little, if anything, if the firm declines in value during the pendency of the bankruptcy proceedings, but may reap much of the benefit of any increase in value. The longer this "option" lasts, the more valuable it is. Ex ante, any expected shift of value to equityholders must reduce the value of the claim of the debtholders.

48 In Katz v Oak Industries, Inc., 508 A2d 873, 878 n 6 (Del Chanc 1986), four institutions held $89 \%$ of the principal amount of one class of the outstanding notes. Four institutions also held $85 \%$ in face amount of the two other classes of notes.

4 See Playtex FP Group Inc., 1988 SEC No-Act LEXIS 1635, *2 (Dec 19) (between 59 and 66 beneficial holders held each of three classes of notes). Note, however, that concentrated ownership does not necessarily ensure collective action. Holdouts can act deceptively. For example, some broker-dealer firms have advised their clients to tender into an issuer's exchange offer, while holding out themselves. See Cowan, NY Times at D6 (cited in note 3) (discussing allegations that R.D. Smith \& Co. did this). Still, the number of recent exchange offers that have been unsuccessful indicates that bondholders often can organize at least to resist an exchange offer they consider inadequate.
} 
Even with concentrated ownership, collective action may still fail. After all, collective action is not the only course of action open to a bondholder that believes the exchange or tender offer proposed by the issuer is inadequate. Rather, some sophisticated bondholders may seek to strike a private deal with the issuer at a higher price offered only to them; in fact, they may recognize that the issuer could not afford to make a similar offer to all bondholders. These bondholders may defect from the coalition formed by the other bondholders in one of two ways: (1) because of their "blocking position" or nuisance value, they may demand a special deal superior to that offered the others; ${ }^{50}$ or (2) they may hold out when the others agree to tender because they realize that, once the corporation's total liability is reduced by the exchange offer, it can afford to pay off their bonds in full at maturity. The key point here is that, although vulture funds can benefit other bondholders by acquiring a blocking position that prevents a corporation from overreaching its bondholders, they may simply use that position to divide with the corporation the gains that the latter could otherwise have exacted from the public bondholders through a coercive exchange offer. When vulture funds appear on the scene after a debt exchange offer is announced and purchase debt securities held by dispersed small bondholders, such a division may be occurring (at least with respect to the difference between the trading price and investment value on the bonds so purchased).

In this light, the premium over the exchange offer received by such a bondholder may represent a wealth transfer from the other bondholders. Moreover, not only do the defecting bondholder's gains potentially come at the expense of the other bondholders, but one bondholder's opportunistic behavior may dissuade the other bondholders from engaging in collective action because they fear they will be exploited by those that hold out or otherwise defect from their coalition. Indeed, if some hold out and are paid in full at maturity, those bondholders who accepted debt securities in the exchange offer may face a new round of renegotiations and

\footnotetext{
so These bondholders may be able to demand a special side deal because they hold a "blocking position." Most bond indentures require a supermajority to amend the bond's covenants. Corporate issuers can use the threat of amending the indenture to coerce the bondholders into accepting an otherwise inadequate exchange offer. See notes 69-76 and accompanying text. However, if a two-thirds vote (in face amount) of the bonds is required to amend the indenture, then the holder or holders of just over one-third of the bonds (in face amount) have blocking position and may demand a higher price for their securities based on its possession. Because bondholders generally do not owe each other fiduciary duties, they are under no obligation not to demand such a premium. Alternatively, some bondholders may simply have a special nuisance value because of their skill and experience in bankruptcy negotiations and their record as persistent litigators.
} 
scaling down because the gains from collective action were lost. In short, the pursuit of potentially zero-sum gains by some bondholders creates capital market uncertainty because it increases the risk for all bondholders that they will not achieve a consensual solution that averts otherwise unnecessary bankruptcy costs. In turn, this uncertainty will cause bondholders to demand ex ante a higher rate of return and therefore will force corporate issuers to pay a higher cost of capital. At this point, the public policy justifications for seeking to facilitate out-of-bankruptcy consensual renegotiations expand beyond ensuring fairness to bondholders and involve the overall efficiency of the capital market for debt. Ultimately, any increase in the cost of capital because of the law's inability to deter opportunistic behavior or to facilitate collective action represents a dead-weight social loss. ${ }^{51}$

\section{The Exchange Offer with Exit Consent and the Prisoner's Dilemma}

The exchange offer is the preferred technique of corporate management to effect a recapitalization and avert insolvency. ${ }^{62}$ The term "exchange offer" refers to an offer by a corporation, usually in the form of a tender offer, to exchange new securities for existing securities.

Our focus is on offers to exchange new securities (mostly debt, but sometimes with a cash component) for existing debt. Within this context, one form of exchange offer has come to predominate: an exchange offer conditioned on the bondholder's "exit consent." To make a complying tender, the bondholder must execute a consent form and deliver it to the offeror, authorizing the offeror to vote the bonds in a manner prescribed by the offeror.

The exit consent relies on the provision found in most bond indentures that permits a specified majority in principal amount of the bondholders to amend the indenture. ${ }^{.3}$ Although the Trust Indenture Act of 1939 provides that bondholders may not alter cer-

s1 It has been estimated that from 1980 to 1989 , U.S. corporations raised $\$ 411$ billion in the equity markets, but $\$ 1.7$ trillion in the bond markets. See Harry P. Kamen, Corporate Responsibilities to Bondholders, in Sametz, ed, Institutional Investing 451 (cited in note 6). Hence, practices that create unproductive uncertainty in a market of this size have considerable public policy significance.

${ }^{82}$ See Salomon Brothers Study at 1 (cited in note 4) (31 exchange offers and $23^{\circ}$ tender offers announced during 1990 for high-yield debt securities).

63 See American Bar Association, Business Law Section, Model Simplified Indenture, 38 Bus Law 741, 763 (1983) (Committee on Developments in Business Financing); American Bar Foundation, Commentaries on Model Debenture Indentures 305 (1971). 
tain "core" provisions of publicly issued debt obligations, ${ }^{54}$ bondholders can agree to eliminate other important protective covenants-for example, covenants prohibiting the firm from paying dividends, covenants requiring the firm to maintain a specified net worth, or covenants prohibiting the firm from incurring debt senior in any respect in right of payment to the debt for which the exchange offer is made..$^{55}$

It is our thesis that the potential power of the corporate issuer to strip the bonds of their protective covenants places the bondholders in a kind of prisoner's dilemma, which coerces the bondholders to accept an exchange offer they would not otherwise accept.. ${ }^{56}$ In Part A, we present the classic prisoner's dilemma. In Part $B$, we demonstrate how exchange offers with exit consents place debtholders in such a prisoner's dilemma.

os Trust Indenture Act of 1939, § 316(b), codified at 15 USC $\S 77 \mathrm{ppp}(\mathrm{b})$ (1988) (prohibiting amendments of the provisions relating to interest, principal, and maturity). Such prohibitions are also customary in debt issues not subject to the Trust Indenture Act. See Kashner, 44 Bus Law at 124 (cited in note 24).

${ }^{8 s}$ In addition, the indenture amendment may expressly subordinate the outstanding class of debt to the new debt offered in the exchange, or it may increase the percentage vote needed to accelerate the debt on default or decrease the vote necessary to make further amendments of the indenture. In the case of secured bonds, an amendment may propose releasing some or all of the collateral.

${ }^{86}$ This problem of constrained choice is common to all tender offers, whether for stock or bonds. See Lucian Arye Bebchuk, The Pressure to Tender: An Analysis and Proposed Remedy, 12 Del J Corp Law 911, 922-25 (1987). Here, the distinctive fact is that bondholders must compare the consideration offered in the exchange or tender offer, not simply with the expected value of the payments promised under the bond contract, but also with the expected decrease in value due to "covenant-stripping" indenture amendments. Thus, there are three values to be compared: (1) the offered exchange price, (2) the current value of the bonds without amendment, and (3) the value of the "amended" bonds. A similar problem can also arise when the firm is involved in a bankruptcy proceeding. During such a proceeding the debtor normally continues to manage the assets and has substantial control over the formulation of a plan of reorganization and the treatment of particular creditors. See Raymond T. Nimmer, Negotiated Bankruptcy Reorganization Plans: Absolute Priority and New Value Contributions, 36 Emory L J 1009, 1017, 1026, 1036 (1987). The debtor can also impose costs on others by delaying the proceedings or by forcing liquidation. Id at 1039. Moreover, the court has the power to force creditors to accept a plan (under the "cramdown" power). Id at 1037. These rules and realities lead to opportunities for the debtor to play each class of creditors off the others.

Outsiders may also try to play the coercion game. For example, in In re Allegheny International, Inc., 118 Bankr 282 (Bankr W D Pa 1990), Japonica Partners, a vulture fund, sought to gain control of Allegheny International, Inc. after Allegheny had entered bankruptcy. Japonica, which previously held no claims against Allegheny, bought sufficient claims of certain classes of creditors to have the voting power to prevent adoption of the debtor's plan. It then sought approval of its own plan. The court held that Japonica had voted in bad faith and that, consequently, its votes should not be counted. Id at 290-91. 


\section{A. The Classic Prisoner's Dilemma}

In the classic prisoner's dilemma, two participants in a criminal act, whom we will call Amy and Bill, are arrested. They are kept in separate rooms, unable to communicate with one another. They are casual acquaintances, with no personal commitment to or influence over one another. The police confront each of them with the following alternatives: "(1) If one of you confesses and agrees to testify as the state's witness, and the other does not, then the one who confesses and testifies will go free and the other will go to jail for twenty years. (2) If both of you confess and agree to testify, both of you will go to jail for ten years. (3) If neither of you confesses, we will get convictions against both of you for minor offenses and both of you will go to jail for one year."

The following matrix reflects Amy's and Bill's options and their consequences. Amy's punishment is first in the list of consequences and Bill's is second:

Amy's Choice

Don't

Confess

Don't

Bill's

Choice

\section{Confess}

Confess
1 yr., 1 yr.

20 yrs., 0

\section{Confess}

If Amy rationally acts in her own self-interest, she will confess and agree to testify. Her reasoning will be as follows: If Bill confesses, Amy is better off if she also confesses, since she will serve ten years in prison rather than twenty. If Bill does not confess, Amy is again better off if she confesses, since she will then go free instead of serving one year in prison. Thus, regardless of what Bill does, Amy is better off if she confesses.

Obviously, the same is true for Bill, since he, by hypothesis, has the same options as Amy. The result is that both will confess and spend ten years in prison. But if they could have communicated with each other and each have committed to refusing to confess, their prison terms would have been only one year. ${ }^{57}$

\footnotetext{
B7 Amy and Bill could get one-year sentences, of course, if somehow they could have agreed to cooperate in advance, with some effective means of enforcement. An important characteristic of the hypothetical facts is that the "game" is a one-shot choice involving people who are not able to communicate with one another. As discussed in Section II.B.3., this characteristic will sometimes be found among debentureholders confronted with an exchange offer.
} 
In this classic form of the prisoner's dilemma, both Amy and Bill have a dominant strategy, so there is a determinate outcome (sometimes called a "Nash equilibrium"): confess, confess. In other words, for each prisoner, the alternative of confessing dominates the alternative of refusing to confess.

\section{B. The Exchange Offer With Exit Consent}

In the following sections, we demonstrate that the position of each debenture holder confronted with either what we term a "Form One Offer"(a conditional tender offer) or a "Form Two Offer"(an offer with payment for consent) is analogous to that of Amy or Bill. Each debenture holder faced with such an exchange offer may accept it, even though they would all benefit by refusing it.

1. The Form One Offer: conditional tender.

The defining feature of what we will call a "Form One Offer" is that the consent and the tender are linked: To make a valid tender, the bondholder must deliver an executed consent to the indenture amendment proposed by the issuer.

To illustrate, assume that a corporation has $\$ 100$ million in face amount of subordinated debentures outstanding, with the principal amount due ten years hence. The corporation offers to pay cash equal to forty-five percent of the face amount of those debentures tendered by bondholders within a specified period of time. The corporation conditions the offer on the tender of at least ninety-five percent of the principal amount of debentures outstanding, that is, $\$ 95$ million worth. The bondholders must accompany their tenders with an executed consent to amend the indenture to eliminate almost all of the significant protective covenants-for example, including a covenant limiting the payment of dividends to shareholders and a covenant prohibiting the firm from incurring debt senior to the debentures. ${ }^{58}$

\footnotetext{
ss This version of a Form One Offer is similar to the offer of $\mathrm{H} C$ Crown Corp., for debentures issued by Univision, Inc. Both $\mathrm{H} \mathrm{C}$ Crown and Univision were wholly-owned subsidiaries of Hallmark Cards, Inc. See Goldman, Sachs \& Co., Offers to Purchase and Consent Solicitations of Univision Holdings, Inc. by H C Crown Corp. (Feb 6, 1990) (on file with $U$ Chi L Rev). The offer was conditioned on a tender of $95 \%$ of the outstanding debentures, but Hallmark later dropped that condition and accepted $93.3 \%$ ( $\$ 251.9$ million of a total of $\$ 270$ million). See Associated Press, Company News; Hallmark Accepts Univision Offer, NY Times D3 (Apr 18, 1990). See also Merrill Lynch Capital Markets and Donaldson, Lufkin, and Jenrette, The Southland Corporation Offers to Exchange and Solicitation of
} 
There are other common versions of the Form One Offer. In one variation, the corporation offers to purchase fifty-one percent of the principal amount of the outstanding debentures, with pro rata acceptance if bondholders tender more than fifty-one percent. $^{58}$ In another variation, the corporation offers securities-either debt or common stock-instead of cash. ${ }^{60}$ For purposes of our analysis, however, the possible variations are not significant.

Suppose that you hold a debenture with a face amount of $\$ 1000$ that trades in a thin market. Right now you cannot find a buyer at any price above $\$ 450$. You have just received a Form One Offer-a conditional tender offer-at $\$ 450$. You think that the true value of the debentures is $\$ 500$ and that, before long, if you and the other debenture holders reject the offer, the market price will rise to that amount. ${ }^{61}$ This will not happen, of course, if a sufficient

Consents and Proxies (Aug 2, 1990) ("Southland Offering Circular") (on file with U Chi L Rev). Southland offered mostly securities in exchange.

It may help the reader to refer to the generic matrix below as we go through various hypothetical prisoner's dilemma matrices:

\begin{tabular}{llll} 
& & \multicolumn{2}{c}{ Your Choice } \\
Sufficient & $\begin{array}{l}\text { Don't Tender } \\
\text { Others' } \\
\text { Choice }\end{array}$ & $\begin{array}{l}\text { Tender offer } \\
\text { fails; you get }\end{array}$ & Tender \\
& Tender & Tender offer \\
& & $\begin{array}{l}\text { Tails; you get } \\
\text { market price }\end{array}$ \\
& Tender & $\begin{array}{l}\text { Tender offer suc- } \\
\text { ceeds; you get }\end{array}$ & Tender offer \\
& & market price as & succeeds; you \\
& influenced by the & get tender offer \\
amendments & price
\end{tabular}

s9 See description of tender offer by Community Newspapers, Inc., in text accompanying notes 70-76.

so See Katz, 508 A2d at 876.

61 Your rejection of the market's seemingly objective appraisal that the debenture is worth $\$ 450$ may be based simply on your own judgment of the debtor's prospects. To this extent, you reject the market's efficiency for this security. The basis for your judgment may, however, involve more complexity and uncertainty than is generally involved in determining value. Debt exchange offers often occur when the corporation is in financial trouble. The corporation may need additional equity capital and the value of the debentures may depend on how much dilution the existing equityholders are willing to accept. See text accompanying notes 92-94. Moreover, the issuer of the debt may be on the verge of bankruptcy, or, short of that, reaching a position where goodwill and other operating values or strategic advantages are lost. Full information about the financial condition of the issuer is likely to be hard to come by. Current investors may be willing to hold on and hope for the best, while new investors may be reluctant to take the risk inherent in the debt.

Other considerations also lend plausibility to a theory of inaccurate, or seemingly inaccurate, market prices. The value of a bond in a workout context may be significantly related to its holder's ability to negotiate. Small holders will usually not invest time or money in 
number of holders accept the $\$ 450$ offer. However, suppose that you also believe that the existing bonds, without their important protective covenants, will be worth only $\$ 400$. Finally, suppose that you do not hold enough debentures to affect the outcome of the tender offer.

In these circumstances, you will tender. Your reasoning will parallel that of each prisoner in the prisoner's dilemma: if the tender offer fails, you will get $\$ 500$, regardless of whether you tender or not. But if the tender offer succeeds and you fail to tender, you will get $\$ 400$ rather than $\$ 450$. Your decision matrix is as follows:

\begin{tabular}{llll} 
& & \multicolumn{2}{c}{ Your Choice } \\
& $\begin{array}{l}\text { Don't } \\
\text { Tender }\end{array}$ & Tender \\
$\begin{array}{l}\text { Sufficient } \\
\text { Others' }\end{array}$ & $\begin{array}{l}\text { Don't } \\
\text { Choice }\end{array}$ & $\$ 500$ & $\$ 500$ \\
& Tender & $\$ 400$ & $\$ 450$
\end{tabular}

Thus, you will maximize your expected wealth if you tender. ${ }^{62}$ All other debtholders will reason the same way and all will tender. The offer will succeed, and the bonds will be worth $\$ 450$. But again, if the bondholders could have cooperated and agreed not to tender, the bonds would have been worth $\$ 500 .^{63}$

extended negotiations, but larger holders (including the new vulture funds) can and do. Thus, an arbitrage process, in which some holders assemble larger positions that may give them a blocking position or that justify expenditures on negotiation and litigation, may result. This arbitrage process may also move the bonds from risk averse holders to risk neutral ones (who will reject a price that a risk averse holder may consider adequate).

We do know, in any event, that Form One Offers have been rejected when holders have been able to communicate with one another effectively. See text accompanying notes 70-76. In the case of the Southland offer, for example, the recent high market price for the senior debentures had been $\$ 490$. See Southland Offering Circular at 150 (cited in note 58). The issuer originally made an offer that was estimated at $\$ 350$, and was described by one business writer as a "raw deal." Schifrin, Enough Already! Forbes at 130 (cited in note 20). The offer was later improved to a package consisting of $\$ 57$ cash, plus 86.5 shares of common stock (presumably worth $\$ 1.50$ per share, the price to be paid for such shares by a new investor), plus $\$ 475$ in face amount of new $12 \%$ debt obligations. See Southland Offering Circular at 10 (cited in note 58). All the proposed exchange offers were rejected by Southland's creditors and eventually Southland was reorganized through a prepackaged bankruptcy.

62 This result holds regardless of the probability you assign to the success of the offer. To state the reasoning differently, there is no circumstance in which you are worse off by tendering. There is, however, a circumstance in which you are worse off by not tendering: if a sufficient number of others tender and the offer is successful.

os The above analysis may make the Form One Offer seem pernicious to debenture- 


\section{Form Two Offer: Offer with payment for consent.}

In the Form Two Offer, the corporate issuer partially separates the tender from the consent by paying for the consent separately.

For example, the issuer may offer to buy thirty percent of the outstanding principal amount of its debentures for $\$ 600$ per $\$ 1,000$ face amount of debenture. In addition, the issuer may offer to pay a premium of $\$ 17.50$ per $\$ 1,000$ debenture for a consent to amend the indenture to eliminate important protective covenants. The issuer conditions the entire offer on receiving sufficient consents to amend the indenture. The issuer pays the consent fee to all those who tender with consent, despite proration of purchases. ${ }^{64}$ Such "vote buying" has become common in debt tender offers. ${ }^{65}$

Suppose that you hold a debenture with a face amount of $\$ 1,000$, a favorable interest rate, and a maturity date ten years hence. The recent market price has been $\$ 1,080$. The market is thin, however, and you think that the debenture's value is $\$ 1,100$. The issuer offers to redeem thirty percent of the outstanding debentures at a price of $\$ 1,070$. The issuer also offers to pay $\$ 17.50$ per debenture for an exit consent to amend the indenture to eliminate a covenant that prohibits the payment of dividends to shareholders (for example, because the corporation has not achieved sufficient earnings). The corporate issuer seeks the amendment in order to pay its customary quarterly dividend. ${ }^{66}$ Suppose further

holders. That appearance may be misleading. The hypothetical facts above dramatize the coercive aspect of such offers. In other settings coercion may serve a benign purpose, as we will explain later. See text accompanying notes 77-101. This benign use of coercion may be why Chancellor Allen, in Katz, objected to the use of the word "coercion" at all. 508 A2d at 879-80. We will suggest, however, that the benign purpose can be achieved without coercion, while the pernicious purpose cannot. That is why we ultimately conclude that the tender offer with exit consent should not be tolerated. See text at beginning of Section IV.

or See Offering Circular of Armco Inc. (Aug 1, 1990) and Supplemental Offer (Sept 13, 1990), in Wall St J C17 (Sept 14, 1990). Armco offered \$1,070, a small premium over the face amount of its bond. The purpose of the Armco offer was to allow it to pay a modest dividend. The debentures had traded in January 1990 for $\$ 107.88$. See 57 Moody's Bond Record 11 (No 1, Jan 1990).

${ }^{\text {os }}$ For example, during 1990, Mary Kay Corp. offered to pay $\$ 10$ in cash for each $\$ 1,000$ principal amount of debentures to holders that consented to the elimination of certain restrictive covenants. Salomon Brothers Study at 10 (cited in note 4). Similarly, Armco, Inc. offered to pay a $\$ 17.50$ fee for each $\$ 1,000$ principal amount to holders of its senior notes that voted to relax a dividend test in its indenture. Id at 12. The highest consent fee we have come across was offered by Holiday Inns, Inc., which offered to pay $\$ 110$ per each $\$ 1,000$ principal amount of its notes in return for consent to indenture amendments. Id at 18. This amounts to $10 \%$ of the total value of the transaction (i.e., tender price plus consent fee). More commonly, the fee is in the $1 \%$ to $2 \%$ range.

es This was the objective of the exchange offer by Armco described in note 64 . 
that, in your belief, the bonds will only be worth $\$ 1,040$ in the market absent this protective covenant. The issuer conditions the entire offer on receiving exit consents representing 50.1 percent of the total principal amount, a number adequate to approve the amendment.

If you are a debenture holder calculating the value of your alternatives, you must initially estimate the effect of proration. Suppose that you think that ninety percent of the debentures will be tendered and that, consequently, one-third ${ }^{67}$ of the debentures you tender will be redeemed for $\$ 1,070$. Suppose that you have three debentures and tender all of them. You will receive $\$ 1,070$ for one of the debentures, plus the $\$ 17.50$ consent fee for each of them, or $\$ 52.50$. You will receive cash of $\$ 1,122.50$, and two of your debentures will be returned to you. Again, you think that those two debentures, after the amendment to the indenture, will be worth $\$ 1,040$ each, or a total of $\$ 2,080$. Thus your expected wealth if the tender is successful and you tender is $\$ 3,202.50$. Your decision matrix is as follows:

\begin{tabular}{lllc} 
& \multicolumn{2}{c}{ Your Choice } \\
$\begin{array}{l}\text { Don't } \\
\text { Tender }\end{array}$ & Tender \\
$\begin{array}{l}\text { Others' } \\
\text { Choice }\end{array}$ & $\begin{array}{l}\text { Don't } \\
\text { Tender }\end{array}$ & $\$ 3,300$ & $\$ 3,300$ \\
& Tender & $\$ 3,120$ & $\$ 3,202.50$
\end{tabular}

If sufficient others (50.1 percent) do not tender, your bonds will be worth $\$ 3,300$, regardless of whether you tender or not. But if sufficient others do tender, you will receive $\$ 3,202.50$ if you tender and only $\$ 3,120$ if you do not. So you tender. But, once again, if the current value of the debentures is in fact $\$ 3,300$-as you believe it is-you would be better off if the tender were unsuccessful. Yet, unless you can reach an agreement with enough other bondholders, you will tender. You are again caught in a prisoner's dilemma. ${ }^{68}$

\footnotetext{
${ }^{67}$ Or $30 \%$ (percentage of outstanding debentures to be redeemed) divided by $90 \%$ (percentage of debentures tendered).

ss Of course, you may be wrong about the value of the debentures: they may only be worth $\$ 1,060$ each. In that case, you and the other holders would be better off if the tender offer were to succeed. Our point, however, is that, even if a majority of the holders think that the debentures are worth $\$ 1,100$, and that the offer is not in their best interests, the offer may still succeed.
} 
3. A real-world example of the prisoner's dilemma.

The prisoner's dilemma posed by the hypotheticals above can easily occur in the real world. Suppose that a corporation is in some financial difficulty and that as a result its debentures are selling at a discount in a thin market. Partly because of rumors of impending bankruptcy proceedings, which the corporation has done nothing to dispel, debenture holders may be unable to find buyers at a reasonable price. Also suppose that the corporation has not released enough financial data to allow investors to arrive at sound valuations of their claims. ${ }^{69}$ At this point, the corporation makes a cash tender offer for the debentures at a low price, requiring that the bondholders include exit consents with their tenders and contingent upon the corporation receiving enough consents to amend the indenture to remove all significant financial covenants. The corporation announces that, if the offer is successful and the indenture is amended, it intends to incur new debt that is senior to the existing debentures.

This scenario closely resembles the 1990 tender offer made by Community Newspapers, Inc. (CNI). ${ }^{70}$ CNI was headed by Ralph Ingersoll, who owned half of the equity. The other half was owned by the venture capital firm of E.M. Warburg, Pincus \& Company. The interest rate on the Community Newspaper obligations was scheduled to be reset on July 7, 1990 at a rate sufficient to make them trade at par, but apparently there was no interest rate high enough to accomplish that objective. ${ }^{71}$

Ingersoll, through his firm, Ingersoll Newspapers, Inc. (INI), offered to buy eighty percent of CNI's Senior Subordinated Reset Notes at fifty-five percent of their face amount. Ingersoll also offered to buy fifty-one percent of CNI's Subordinated Discount Debentures at twenty-five percent of their face amount, contingent upon the bondholders' consent to strip both issues of all of their

Bo There is widespread discontent among debtholders about the inadequacy of the information they are able to obtain. See Colloton, Bondholder Communications-The Missing Link in High Yield Debt at 34-40 (cited in note 31).

70 See Goldman, Sachs \& Co., Offers to Purchase and Consent Solicitations of Community Newspapers, Inc., by Ingersoll Newspapers, Inc. (Mar 22, 1990) ("CNI Offering Circular") (on file with U Chi L Rev). The background of the CNI offer is described in Benjamin J. Stein, Insult to Injury: Junk Holders Get Offers They Should, But Can't, Refuse, Barron's 42 (May 28, 1990).

71 See CNI Offering Circular at 10 (cited in note 70). The problem with the reset provision is in part that as the rate is raised, the increased interest burden increases the risk of default. See William A. Klein and John C. Coffee, Jr., Business Organization and Finance 335-38 (Foundation Press, 4th ed 1990). 
significant protective covenants. ${ }^{72}$ Among other objectives, this stripping would have permitted Ingersoll to subordinate the debt to other debt. Ingersoll would then have financed the buy-back by issuing new debt senior to the existing debt. ${ }^{73}$ Ingersoll claimed that he was bestowing a benefit on the debtholders, some of whom, he claimed, had asked to be bought out.

One analyst claimed that the true value of the senior debentures was eighty percent of their face amount. ${ }^{74}$ One investor called the offer "insulting," and the bondholders twice rejected it. ${ }^{75}$ Ultimately, Ingersoll withdrew his offer and swapped with E.M. Warburg, Pincus, so that it became the sole owner of CNI. ${ }^{78}$ Apparently, the bondholders, which were mostly institutions, were few enough that they could communicate their dissatisfaction to each other. Hence they were able to act collectively, avoid the prisoner's dilemma, and reject the offer.

\section{Vulture Funds and the Holdout Problem}

The preceding discussion suggests a simple policy reform: curtail coercion by making it more difficult to amend the indenture, at least in the case of issuer-proposed exchange or tender offers. But this reform ignores the problem of the opportunistic holdout. Ultimately, eliminating all elements of coercion from the recapitalization context would also disarm the ability of the majority of the bondholders to discipline holdouts, and would thereby expose them to greater uncertainty. In the last analysis, unproductive uncertainty is the enemy of both most bondholders and the corporate issuer because it raises the cost of capital, while benefiting only those few bondholders whose strategic positions or special expertise allows them to exploit and profit from it.

72 See CNI Offering Circular at 1-2 (cited in note 70).

73 Id.

74 See Eric N. Berg, Ingersoll Scrambles to Avoid Default, NY Times D1, D2 (Mar 23, 1990).

7s Beth Selby, Bondholders Rebel Against Ingersoll Newspapers, Institutional Investor 23 (Jun 1990). Another newspaper account cited Ingersoll's offer as an "egregious example" of exchange offers being used "abusively," in reliance in part on the bankruptcy laws, "which allow owners to operate and retain control of failed companies during lengthy periods of 'reorganization," " and which "give considerable latitude to unscrupulous bond issuers immune to the stigma of default." Larry Black, View from New York: Drexel Paves the Way for a Comeback, Independent 25 (Jun 4, 1990).

7o See Alex S. Jones, Ingersoll, in Swap, Sheds His U.S. Papers, NY Times D1 (Jul 3, 1990). Warburg, Pincus ultimately offered to redeem the bonds for 74 cents on the dollar, but a substantial holder held out, the offer failed, and the company was forced into bankruptcy. See Cowan, NY Times at C1 (cited in note 3); Linda Sandler, Battles on Two Junk Bond Fronts: Offer by Chain of Newspapers Is Threatened, Wall St J C1 (Jan 28, 1991). 
To understand these contentions, it is useful to begin by understanding how it might be in the debtholders' interest to reduce their claims. For example, reducing the outstanding debt may induce equityholders to invest new money in the firm. This additional capital may finance a profitable venture or stave off bankruptcy, benefiting both debtholders and equityholders. In such settings, coercive exchange offers can solve a holdout problem among the debtholders and facilitate the beneficial transaction. The following subsections present two such settings: (1) when a firm needs capital to finance a profitable project, and (2) when a firm needs capital to avoid insolvency.

\section{A. Financing a Profitable Project}

Professor Stewart Myers has identified a situation in which the value of a firm - and the value of the debt and equity elaimscan be maximized only if the debtholders agree to scale back their claims. ${ }^{77}$ That circumstance can best be described by hypothetical facts. ${ }^{78}$

Suppose that $X$ Corp. begins in Year 1 with assets of $\$ 2,000$, debt of $\$ 1,000$, and equity (common stock) of $\$ 1,000$. The debt bears a market rate of interest and is due at the end of Year 20.

The firm's initial financial status is shown in Balance Sheet A:

\begin{tabular}{ccc|ccc}
\multicolumn{6}{c}{ Balance Sheet A } \\
Assets & \multicolumn{3}{c}{ Liability and Equity } \\
Investments & Book & Mkt & & Book & Mkt \\
& $\$ 2,000$ & $\$ 2,000$ & Debt & $\$ 1,000$ & $\$ 1,000$ \\
& & & Equity & 1,000 & 1,000
\end{tabular}

Over the next ten years, the firm does poorly. At the end of Year 10, the firm's assets carry a book value of $\$ 1,200$, but have a market value of only $\$ 800 .{ }^{79}$ In other words, the firm has shown (1977).

77 Stewart C. Myers, Determinants of Corporate Borrowing, 5 J Fin Econ 147, 158

${ }^{78}$ This analysis is taken, with minor changes, from Klein and Coffee, Business Organization and Finance at 237-40 (cited in note 71). We are grateful to The Foundation Press, Inc., holder of the copyright, for permission to use this material. See also William Klein, The Put-Up-Or-Shut-Up Strategy in Business Negotiations, 17 U Cal Davis L Rev 341, 342-51 (1983) (similar problem in context of real estate limited partnership).

70 The analysis does not depend on the bonds selling for less than face amount, though it does depend on the bonds having some significant risk of default. If the bonds do have a 
losses of $\$ 800$ on its books (the decline from $\$ 2,000$ to $\$ 1,200$ ), but in fact has sustained an additional, unrealized, loss of $\$ 400$. Balance Sheet B shows the firm's financial status after ten years:

\begin{tabular}{|c|c|c|c|c|c|}
\hline & \multicolumn{3}{|c|}{ Balance Sheet B } & & \\
\hline & \multicolumn{2}{|c|}{ Assets } & \multicolumn{3}{|c|}{ Liability and Equity } \\
\hline & Book & Mkt & & Book & Mkt \\
\hline Investments & $\$ 1,200$ & $\$ 800$ & Debt & $\$ 1,000$ & $\$ 700$ \\
\hline & & & Equity & 200 & 100 \\
\hline
\end{tabular}

Assume further that the firm has paid the interest on the debt, and that the debt is not in default. ${ }^{80}$ Assume that the sole reason why the debt is worth $\$ 300$ less than its face amount is default risk; the market rate of interest has not changed. ${ }^{81}$ While the claim of the debt exceeds the value of the firm, the equity "captures" some of the firm's value: the equity is like an option to buy the firm from the bondholders for $\$ 1,000$ any time within the next ten years, subject to an obligation to make interest payments to keep the option in effect. ${ }^{82}$ This option has value even though, if the firm were liquidated correctly, the equity would receive nothing.

Suppose that X Corp.'s managers become aware of an opportunity to invest in a project with a cost of $\$ 550$ and an estimated present value of $\$ 800$. Only this firm can develop the project; it

market value equal to or greater than par, however, the underinvestment problem discussed in the text may be avoidable by redeeming them under an optional redemption right (a call provision).

${ }^{\text {so }}$ If the indenture contained a covenant requiring the firm to maintain an equity cushion of, say, at least half the amount of the debt, then the firm would be in default, and, most likely, the full amount of the debt would become due and payable. The firm presumably could not pay and could be forced into bankruptcy.

s1 The following assumptions illustrate how the relative values of the debt $(\$ 700)$ and equity (\$100) might arise:

\begin{tabular}{|c|c|c|c|c|c|c|}
\hline \multirow[b]{2}{*}{ Probability } & \multicolumn{3}{|c|}{$\ldots-$ - Outcome $\ldots$} & \multicolumn{3}{|c|}{. . . . . Value . . . . - } \\
\hline & Firm & Debt & Equity & Firm & Debt & Equity \\
\hline 0.1 & & & $\$ 0$ & $\$ 0$ & $\$ 0$ & \\
\hline 0.8 & 750 & 750 & 0 & 600 & 600 & 0 \\
\hline 0.1 & 2,000 & 1,000 & 1,000 & 200 & 100 & 100 \\
\hline & & & Total & $\$ 800$ & $\$ 700$ & $\$ 100$ \\
\hline
\end{tabular}

${ }^{82}$ See Klein and Coffee, Business Organization and Finance at 44-47, 271-75 (cited in note 71). 
cannot be sold. ${ }^{83}$ Suppose further that the project has a zero variance of expected returns ${ }^{84}$ and must be financed with new equity.

One financing option is a rights offering: ${ }^{85}$ by setting the price low enough, the firm's management could force the existing shareholders to subscribe to the offering because otherwise the proportionate interest of non-subscribing shareholders would be diluted. In effect, these shareholders would transfer wealth to those who did subscribe. ${ }^{86}$ If this subscription approach were used, the book value of the firm's assets would increase by the $\$ 550$ contribution to $\$ 1,750$, and the market value would increase by the $\$ 800$ value of the project to $\$ 1,600$. However, the market value of the debt would also increase by $\$ 300$, because, with the value added by the new project, there would no longer be any risk of default. Thus, the equity would increase in value by only $\$ 500$. Balance Sheet C shows the post-offering results:

\begin{tabular}{|c|c|c|c|c|c|}
\hline & & Balance & & & \\
\hline & & & Liabili & and Equ & \\
\hline Investments & $\begin{array}{c}\text { Book } \\
\$ 1,750\end{array}$ & $\begin{array}{c}\text { Mkt } \\
\$ 1,600\end{array}$ & Debt & $\begin{array}{c}\text { Book } \\
\$ 1,000\end{array}$ & $\begin{array}{c}\text { Mkt } \\
\$ 1,000\end{array}$ \\
\hline & & & Equity & 750 & \\
\hline
\end{tabular}

In short, the project would increase the value of the firm by $\$ 250$ - the difference between the increased value of the firm and its securities $(\$ 800)$, and the cost of producing that increase (that is, the amount of the additional equity investment, \$550). If, how-

\footnotetext{
ss The project might, for example, be to repair or improve the firm's existing plant.

84 In other words, it is a sure thing. This assumption simplifies the explanation but its rejection would not affect the basic analysis. Implicit in the numbers used in the example in the text is the assumption that the existing investment has some variance in expected outcomes. See note 81. If the new project does have some variance in expected outcomes, that variance may be either positively or negatively correlated with the variance of the existing investment. If the correlation is negative, the combined variance is reduced, which will tend to benefit the debt at the expense of the equity, magnifying the conflict discussed in the text. If the correlation is positive, the combined variance is magnified, which will benefit the equity. In fact, if the variance of the new project is the same as, and perfectly correlated with, the variance of the existing project hypothesized in note 81, it turns out that once the new project is added, the value of the bonds is $\$ 900$ and the value of the equity is $\$ 700$. With these numbers, the problem presented in the text disappears. It is certainly possible, however, to hypothesize numbers for which the problem does not disappear, even with a positive correlation.

ss In a rights offering, the corporation issues to its shareholders the right to subscribe to its shares for a limited period at a price below their current market value. The shareholders thus receive a bargain, while the issuer saves the standard underwriters' discount. See Klein and Coffee, Business Organization and Finance at 256-58 (cited in note 71).
}

si Id. 
ever, the managers seek to maximize shareholder wealth, they will in fact reject the project because it would decrease shareholder wealth by $\$ 50$ (the post-investment value of the common stock $(\$ 600)$, less the additional equity cost $(\$ 550)$, less the pre-investment value of the common stock $(\$ 100)) .{ }^{87}$ In other words, the project increases the firm's value by $\$ 250$, but the infusion of new equity shifts $\$ 300$ of firm wealth to the bondholders. ${ }^{88}$ Other have referred to this phenomenon as a "buoying-up" of the debt. ${ }^{89}$

Note that the conflict between the equity and the debt depends upon the duration of the debt. If the debt were due soon, the common shareholders could not pay it and the debt would be in default. If the bankruptcy procedure operated quickly, without cost, and with a rule of absolute priority, the bondholders would take over the assets of the firm, including the new business opportunity. Thus the bondholders would undertake the new project, and the firm would be worth $\$ 1,050 .^{90}$. In fact, even if the debt were due and in default, the firm's managers probably could file for protection under Chapter 11 of the Bankruptcy Code.91 This would carry with it the threat of delay and the corresponding threat of losing the value of the prospect. The result would be that the shareholders would be required to share the $\$ 250$ potential gain with the bondholders; otherwise, the bondholders would carry out their threat and the gain would be lost.

One means by which bondholders and shareholders could share the potential gain would be for the bondholders to agree to reduce their claims, for example, to $\$ 800$. The effect would be to

87 The same result obtains if the new equity is raised by issuing new shares to outsiders. For their $\$ 550$ contribution, the outsiders would, of course, demand shares worth $\$ 550$. Since the total equity would be worth $\$ 600$, that would leave the original shareholders with shares worth only $\$ 50$, or $\$ 50$ less than what they started with. This observation leads to the further observation that the bondholders would be protected by a covenant requiring the firm to maintain an equity cushion of, say, $\$ 750$, and explicitly requiring that the firm raise new equity capital if necessary to comply with that requirement. Merely treating the failure to maintain the specified equity cushion as an act of default may have much the same effect.

${ }^{88}$ As indicated in note 84 , if the new project has a variance identical to and positively correlated with the variance hypothesized in note 81 , the value of the bonds will be $\$ 900$ and the value of the equity will be $\$ 700$. In this situation, the contribution of an additional $\$ 550$ in equity results in an increase in the value of the equity of $\$ 600$ (to $\$ 700$ from $\$ 100$ ), so the investment presumably will be made.

${ }^{89}$ See Roe, 97 Yale L J at 233 n 3 (cited in note 24).

90 Note that with the firm worth $\$ 1,050$, and bondholders' claims of $\$ 1,000$, the common shareholders would be entitled to securities worth $\$ 50$. This observation helps explain why a firm may be worth more after insolvency reorganization than before and why, as a result, the common shareholders may be entitled to some of the shares of the reorganized firm even though, before the reorganization, its liabilities exceeded its assets.

11 USC § 1101 et seq (1988). 
increase the value of the debt by $\$ 100$ from its initial value of $\$ 700$. At the same time, the value of the equity would rise to $\$ 800$. In other words, because the market value of the debt and equity claims together were $\$ 1,600$, the reduction of the debt claims from $\$ 1,000$ to $\$ 800$ would increase the market value of the equity claims from $\$ 600$ to $\$ 800$. By investing $\$ 550$, the equityholders would increase the value of their equity from $\$ 100$ to $\$ 800$, for a net gain of $\$ 150$ ( $\$ 800$, less the $\$ 550$ of additional equity, less the $\$ 100$ pre-investment value). Thus, the equityholders would have a strong incentive to contribute the additional capital, and the debtholders would have a strong incentive to accept a reduction in the amount of their claim.

Suppose all the bondholders see that it is in their best interests to accept a reduced claim, or "haircut." Suppose that the corporation has made an exchange offer under which each $\$ 1,000$ (face amount) bond would be exchanged for a new $\$ 800$ bond. If a bondholder confronted with this offer were to hold out, and enough other bondholders were to tender, the exchange would succeed and the bondholder would still hold a $\$ 1,000$ bond. Conversely, if enough bondholders were also to hold out, the exchange would not succeed and everyone would lose. ${ }^{92}$ Again, what seems individually rational is not collectively rational.

Still, bondholders can achieve what is collectively rational for them by devising a means to preclude holding out. As already noted, adding an exit consent to the exchange offer can reduce the incentive to hold out. ${ }^{93}$ But this technique will not always be effective as a coercive device. It has the intended coercive effect only where stripping the covenants makes the existing obligations of the firm worth less than the new obligations offered in the exchange. For example, a corporation might offer new obligations worth $\$ 800$. But if the existing obligations, with a face amount of $\$ 1,000$, were worth more than $\$ 800$, even without their protective covenants, and even with the existing obligations subordinated to the new, ${ }^{94}$ the holdout problem would remain.

\footnotetext{
${ }^{92}$ For a real-world version of this holdout problem, see Floyd Norris, Lindner Promise: A Delicate Game, NY Times D8 (Jun 27, 1990).

os Where the bonds are not publicly held, the indenture could allow amendment by majority (or some higher percentage) vote to reduce the claim. That is a simple way to solve the holdout problem. But, as stated earlier, in the case of publicly issued bonds, amendment of core provisions is not permitted. See text accompanying notes 53-56.

04 This could be the case if the exchange offer is successful, new equity capital is invested, and the existing debt is buoyed up. It could also happen if the maturity date on the existing debt is fast approaching.
} 
Even if the bondholders were prepared to reduce their claims, they would still need to agree with the equityholders over how to divide the $\$ 250$ increase in the firm's value. The outcome of the bargaining process is indeterminate. The result may be an impasse, as the two sets of claimants match their collective risk aversion, greed, and resolve. Economists refer to this scenario as a "bilateral monopoly" problem. The exchange offer with exit consent may solve the bilateral monopoly problem, but this solution gives the equityholders the unilateral power to decide how to divide the gain.

In some circumstances the firm can raise additional capital, without either buoying up the existing debt or reducing the value of the equity, by issuing senior debt. ${ }^{95}$ For example, on the above facts, both the existing debtholders and the existing equityholders would be better off if the firm were to issue new senior debt to finance the project. ${ }^{96}$ Of course, if the terms of the existing debt prohibit subordination, the debtholders would have to vote to ap-

ss Ideally, the new debt should have a senior claim only on the new project. See Elazar Berkovitch and E. Han Kim, Financial Contracting and Leverage Induced Over- and Under-Investment Incentives, $45 \mathrm{~J}$ Fin 765, 766 (1990).

96 Return to the distribution of expected outcomes hypothesized in note 81. Assuming that the new project is worth $\$ 800$, with zero variance, the new distribution of outcomes and resulting values is as follows (with the total debt claim now $\$ 1,550$ ):

$\begin{array}{crrrrrr} & & \ldots & \text { Outcome } & \ldots & \ldots \ldots & \text { Value } \\ \text { Probability } & \text { Firm } & \text { Debt } & \text { Equity } & \text { Firm } & \text { Debt } & \text { Equity } \\ 0.1 & \$ 800 & \$ 800 & \$ 0 & \$ 80 & \$ 80 & \$ 0 \\ 0.8 & 1,550 & 1,550 & 0 & 1,240 & 1,240 & 0 \\ 0.1 & 2,800 & 1,550 & 1,250 & 280 & 155 & 125 \\ & & & \text { Total } & \$ 1,600 & \$ 1,475 & \$ 125\end{array}$

Of the total value of $\$ 1,475$ for the debt, $\$ 550$ is allocable to the new senior debt and the remaining $\$ 925$ is allocable to the existing, now subordinated debt. Thus, the existing debtholders gain $\$ 225$, while the equityholders gain $\$ 25$. The equityholders might demand a larger share of the gain and might, therefore, use an exchange offer with exit consent to require the existing debtholders to accept a reduced claim.

It is possible, of course, that the new project might reduce the variance of outcomes. Suppose, for example, that with the new project completed the expected outcomes and values are as follows:

\begin{tabular}{|c|c|c|c|c|c|c|}
\hline \multirow[b]{2}{*}{ Probability } & \multicolumn{3}{|c|}{$\ldots \ldots$ Outcome $\ldots \ldots$} & \multicolumn{3}{|c|}{$\ldots \ldots$ Value $\ldots \ldots$} \\
\hline & Firm & Debt & Equity & Firm & Debt & Equity \\
\hline 0.1 & $\$ 1,100$ & $\$ 1,100$ & $\$ 0$ & $\$ 110$ & $\$ 110$ & $\$ 0$ \\
\hline 0.8 & 1,550 & 1,550 & 0 & 1,240 & 1,240 & 0 \\
\hline 0.1 & 2,500 & 1,550 & 950 & 250 & 155 & 95 \\
\hline & & & Total & $\$ 1,600$ & $\$ 1,505$ & $\$ 95$ \\
\hline
\end{tabular}

In this situation, the issuance of subordinated debt reduces the value of the equity from $\$ 100$ to $\$ 95$ and presumably a reduction of the claim of the existing debt would become a non-negotiable demand of the equityholders. 
prove an amendment of the indenture permitting the senior debt issuance.

Issuing senior debt avoids the holdout problem, but it does not solve the bilateral monopoly problem; the possibility of a mutually destructive impasse remains. ${ }^{97}$

\section{B. Avoiding Insolvency}

The preceding analysis of the buoying-up phenomenon is also applicable to a firm that is on the verge of bankruptcy and needs

97 There is a similar situation in which it may be in the best interests of the debtholders to scale back their claims: when equity will be taken out of the corporation. See Klein and Coffee, Business Organization and Finance at 243-44 (cited in note 71). Imagine a firm whose financial condition is reflected in Balance Sheet D:

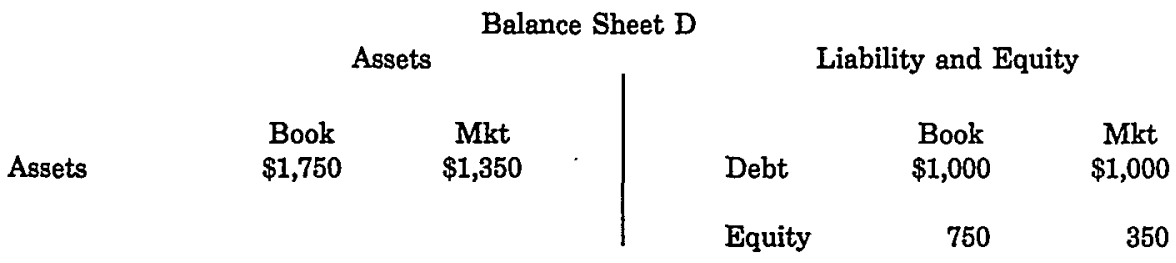

Suppose that the assets include $\$ 550$ in cash and that distribution of this cash to shareholders as a dividend is not prohibited by the terms of the loan agreement, by the corporate-law rules relating to dividends, see Bayless Manning and James J. Hanks, Jr., Legal Capital (Foundation Press, 1990); Klein and Coffee, Business Organization and Finance at 197-99 (cited in note 71), or by rules relating to fraudulent conveyances, see Robert Clark, Corporate Law 40-52 (Little Brown, 1986). Suppose further that if the cash is retained it can be invested in a project that will increase the firm's value by $\$ 800$. If the cash is distributed the results are as reflected in Balance Sheet E:

\begin{tabular}{lc|cccc}
\multicolumn{2}{c}{} & \multicolumn{2}{c}{ Balance Sheet $\mathrm{c}$} & \multicolumn{3}{c}{ Liability and Equity } \\
& & & & & \\
Assets & Book & Mkt & & Book & Mkt \\
& $\$ 1,200$ & $\$ 800$ & Debt & $\$ 1,000$ & $\$ 700$ \\
& & & Equity & 200 & 100
\end{tabular}

The wealth of the debtholders will decline from $\$ 1,000$ to $\$ 700$. The value of the shareholders' equity will decline from $\$ 350$ to $\$ 100$, but they will have the $\$ 550$ in cash, so their total wealth will be $\$ 650$. The debtholders' $\$ 300$ loss is the equityholders' $\$ 300$ gain. But now the firm will pass up a project that would increase its value by $\$ 250$. Payment of a dividend as large as $\$ 550$ may seem unrealistic, but smaller dividends paid regularly over time could have the same effect. The profitable project might not be a single investment (for example, rehabilitating a hotel), but rather, periodic investments in maintenance and repair.

Lastly, suppose the debtholders were willing to reduce their claims to $\$ 800$ if the equityholders agreed to forgo the dividend and invest in the project. The results are those reflected in Balance Sheet F: 
new capital. ${ }^{88}$

To illustrate, return to Balance Sheet $B$ and assume that it represents the outcome if the firm enters bankruptcy. The claim of the debt exceeds the market value of the assets, but the equity still has some value because of its blocking or "holdup" power-that is, its power to delay restructuring and rehabilitation. ${ }^{99}$ If the firm can raise new money and avoid bankruptcy, the outcome is Balance Sheet C. The "project" that generates an additional $\$ 250$ is simply the avoidance of the costs of bankruptcy. This "project" is an example of a "workout" designed to stave off bankruptcy. But workouts require haircuts, giving rise to the holdout problem. Once again, an exchange offer with exit consent can solve this holdout problem, but it remains subject to the possibility of a bilateral monopoly impasse.

\section{A Real-World Example of Beneficial Coercion}

To demonstrate the reality of the above analysis, consider the facts in the leading case on the use of exit consents, Katz v Oak Industries Inc. ${ }^{100}$ The court observed that Oak Industries was "in

\begin{tabular}{|c|c|c|c|c|c|}
\hline \multicolumn{6}{|c|}{ Balance Sheet F } \\
\hline \multirow[b]{2}{*}{ Assets } & \multicolumn{2}{|c|}{ Assets } & \multicolumn{3}{|c|}{ Liability and Equity } \\
\hline & $\begin{array}{c}\text { Book } \\
\$ 1,750\end{array}$ & $\begin{array}{c}\text { Mkt } \\
\$ 1,600\end{array}$ & Debt & $\begin{array}{c}\text { Book } \\
\$ 1,000\end{array}$ & $\stackrel{\text { Mkt }}{\$ 800}$ \\
\hline & & & Equity & 750 & 800 \\
\hline
\end{tabular}

The equityholders will be better off than they would be if they paid themselves a dividend. But the debtholders will also be better off. Their claims will be worth $\$ 800$ instead of the $\$ 700$ they would be worth in the absence of agreement.

Once more we see a situation in which it is in the interest of debtholders to scale back their claims. And once again, unless the holdout problem can be solved, that result may not be achievable.

28 Professor Roe also discusses the holdout problem in situations in which new capital is not needed but the debtholders must scale back their claims in order to avoid the costs and losses associated with bankruptcy. See Roe, 97 Yale L J 232 (cited in note 24). Professor Roe anticipates many of the observations and much of the analysis in this Article. His perspective differs from ours, however, and we add some qualifications to his analysis.

'o See Raymond T. Nimmer, Negotiated Bankruptcy Reorganization Plans: Absolute Priority and New Value Contributions, 36 Emory L J 1009 (1987). "[A]s a general matter, bankruptcy law substitutes a theme of debtor protection for a state law theme of creditor dominance in debt collection matters." Id at 1082. See also Kashner, 44 Bus Law 123 (cited in note 24).

100508 A2d 873. A more recent illustration is found in the attempted recapitalization of The Southland Corporation. See note 58. Southland was on the verge of bankruptcy. ItoYokado, a Japanese firm that had brought Southland's 7-Eleven stores to Japan, had agreed to invest $\$ 430$ million in return for $70 \%$ of Southland's common stock, but the investment 
deep trouble," having experienced "unremitting losses" for the previous forty-five months. ${ }^{101}$ The price of the common stock had fallen from $\$ 30$ to $\$ 2$ per share and the debt was trading at "substantial discounts." 102 Oak plainly needed an infusion of equity capital, and reached an agreement with Allied-Signal, Inc., under which Allied-Signal would buy part of the Oak assets for $\$ 160$ million in cash and would invest an additional \$15 million in Oak's common stock and warrants. Allied-Signal conditioned these investments on the bondholders tendering a certain minimum amount of the debt into an exchange offer by Oak. Under the exchange offer, Oak would pay cash, varying in amounts from $\$ 918$ to $\$ 665$ per debenture for various classes of debt. These amounts "appear[ed] to represent a premium over the market prices for [Oak's] debentures as of the time the terms of the transaction were set."103 The bondholders were to accompany their tenders with exit consents for amendments eliminating several protections in the original indenture, including "all financial covenants." 104 Without the amendments, Allied-Signal was unwilling to make either the $\$ 15$ million equity investment or the $\$ 160$ million purchase of assets.

In short, in the circumstances described by the court, it appears that the corporation needed new equity to preserve the remaining value of the firm, that the investment of the new equity was contingent on a reduction of the debt claims, and that the corporation used exit consents to induce debtholders to accept a deal that was in their best interests.

IV. The Form Three Offer and Prepackaged Bankruptcy: Solutions to the Prisoner's Dilemma and Holdout Problems

Most exchange offers are neither purely benign, designed to solve the holdout problem in the presence of a need for additional capital, nor purely pernicious, designed to victimize debtholders by foisting upon them obligations worth less than the current value of their claims. Instead, many such offers are "hybrids," designed to serve both objectives.

For example, consider a corporation in financial trouble and in need of new capital. A reduction in the claims of the debtholders

was contingent on scaling back the debt. See Matthew Schifrin, Bondholders Fight Back, Forbes 10 (Aug 20, 1990) (focusing on how the debtholders had held out for a better deal than was initially offered).

${ }^{102} \mathrm{Katz}, 508 \mathrm{A2d}$ at 875.

102 Id at $875 \mathrm{n} 2$.

103 Id at 877.

206 Id. 
may be essential to the creation or preservation of value for the firm. In this setting, however, the equityholders (represented by incumbent management), may take advantage of the need for recapitalization by offering the debtholders too little. The "too little" may be blatant-an amount, for example, that is less than the value of the debt in bankruptcy. Or it may simply be an inadequate share of the gains from cooperation. In this situation, the exchange offer may serve a benign purpose in maximizing the value of the firm, but it may nonetheless be an offer that the debtholders would refuse if presented with an unconstrained choice.

Thus, our goal is to devise a regime that will both prevent corporate issuers from coercing the bondholders to accept unfavorable restructurings and at the same time allow bondholders to scale back their claims when it would benefit them. In Part A, we present a third kind of exchange offer with exit consent: the Form Three Offer, in which the corporate issuer conditions the offer on the prior vote by the bondholders to approve an amendment of the indenture agreement. It is our thesis that the Form Three Offer will eliminate the prisoner's dilemma problem, so that the bondholders will be free to accept beneficial restructurings and reject unfavorable restructurings.

Even if the Form Three Offer is superior to the Form One and Form Two Offers, it is not necessarily the best solution to collective action problems in corporate workouts and reorganizations. Bankruptcy law similarly has been viewed as providing a solution to such collective action problems, ${ }^{105}$ and recently the prepackaged bankruptcy plan has emerged as an alternative mechanism for avoiding the holdout problem aggravated by the rise of the vulture fund. Part B contrasts and compares the Form Three Offer with the prepackaged bankruptcy plan and concludes that neither is a complete substitute for the other. At the very least, however, the availability of both of these less coercive options undercuts any justification for Form One or Form Two Offers.

\section{A. Form Three Offer: Offer Conditioned on Vote}

We call our proposed solution the Form Three Offer. In a Form Three Offer, unlike the Form One and Form Two Offers, the

\footnotetext{
${ }^{105}$ See, for example, Douglas G. Baird and Randal C. Picker, A Simple Noncooperative Bargaining Model of Corporate Reorganizations, $20 \mathrm{~J}$ Legal Stud 311 (1991) (arguing that the traditional approach to bankruptcy law neglects some of the important effects of the law).
} 
consent must precede the tender offer. The essential feature of a Form Three Offer is that a bondholder has the right to vote against the amendment without sacrificing the right to exchange if the majority (in interest) of the bondholders approves the amendment. Unlike the Form One and Form Two Offers, the Form Three Offer does not appear to be in use today.

For example, the corporation might offer to buy back all of its debentures for a package of cash and securities worth sixty percent of the principal amount. The corporation would condition the offer on a prior vote of the debenture holders to eliminate important protective covenants. If the debenture holders were to vote to eliminate the covenants, the offer to purchase would become irrevocable and unconditional. But if the debenture holders were not to agree to eliminate the covenants, the offer would be canceled. It is vital that an individual bondholder could vote against stripping the covenants and subsequently tender its debentures if the requisite majority of the bondholders approved the proposed amendments. ${ }^{106}$ As we will discuss later, such a procedure eliminates most of the objectionable features in current attempts to coerce bondholders. ${ }^{107}$

Most importantly, the Form Three Offer, through its use of the prior vote, eliminates the prisoner's dilemma. The offer only succeeds if a majority of debtholders finds it to be in their best

${ }^{108}$ The issuer may wish to tie the vote on the amendment to the conditional tender. In other words, the vote on the amendment becomes a vote on whether to entertain the offer. Professor Bebchuk has proposed a similar procedure, to solve the problem of "distorted" choice in tender offers to shareholders in takeover bids. See Lucian Arye Bebchuk, The Pressure to Tender: An Analysis and a Proposed Remedy, 12 Del J Corp L 911, 931-32 (1987). The objective of his proposal "is to enable shareholders to express their preferences concerning the bid's success separately from their desire to have their shares acquired in the event of a takeover." Id at 931. While Professor Bebchuk describes impediments to solutions to the shareholder distorted-choice problem by charter amendment, id at 935-41, there appear to be no comparable impediments to a private law solution to the problem in the debt context. There is no reason why bond indentures cannot be drafted to prohibit constrained- or distorted-choice offers.

${ }^{102}$ Coercive pressure still remains if the corporation can pay for the vote, because the corporation can split the total premium being offered into two components: one paid for tender and one for voting. Ideally, it should be costless to a bondholder to oppose the decision at the voting stage. Yet, if by voting against the proposed plan, the bondholder is either denied the ability to tender or sacrifices some portion of the premium, then opposition is not costless. If vote buying is to be permitted, it would be less objectionable if the bondholder continued to enjoy the right to vote on a belated basis after the outcome were known (and receive the same vote payment therefor). Then, if the offer succeeded, the bondholder could vote in favor, tender, and receive the same total premium as other bondholders who initially approved the plan. For a discussion of the debatable legitimacy of vote buying in this context, see text accompanying notes 183-86. 
interests. At the same time, once the majority approves the offer, all debtholders have a strong incentive to tender.

To illustrate, suppose that the facts are as in the preceding discussion about financing a profitable venture. The firm has bonds outstanding with a total face amount of $\$ 1,000$ and a current market value of $\$ 700$; its equity is worth $\$ 100$. The firm has an opportunity to invest $\$ 550$ in a way that will increase its total value by $\$ 800$, but the effect would be to buoy up the value of the bonds from $\$ 700$ to $\$ 1,000$, and to reduce the value of the equity from $\$ 100$ to $\$ 50$. The equityholders will be unwilling to invest the $\$ 550$ unless the debtholders agree to reduce their claims. In short, there is a potential $\$ 250$ gain to be shared, if only the equityholders and debtholders can agree on how to share it.

Suppose, then, that the firm makes a Form Three Offer to exchange the existing bonds for new bonds with a face amount, and expected market value, of $\$ 800$. The equityholders promise that, if the offer succeeds, they will contribute the $\$ 550$ to the firm to fund the new project. The firm conditions its exchange offer on a prior vote by the bondholders to amend the existing bond indenture to eliminate all of the important protective covenants. Stripped of their covenants, the existing bonds would be worth only $\$ 700$.

Unless the bondholders believe that they can squeeze more of the $\$ 250$ gain out of the equityholders, it is in their interest that the exchange succeed: the value of their claims will be $\$ 800$ if the exchange were to succeed rather than $\$ 700$ if it does not. Therefore, if a majority of the bondholders consents to the amendment of the indenture, each bondholder will be confronted with a choice between keeping a bond worth only $\$ 700$ or exchanging it for a new bond worth $\$ 800$. The outcome is obvious: the exchange offer will succeed and everyone will be better off.

In this scenario, there is coercion at the final stage, but the bondholders will have imposed it upon themselves. The bondholders are never confronted with a prisoner's dilemma. Ultimately, a majority of the bondholders will have coerced the rest to do what the majority deemed to be in the bondholders' collective best interest. If the majority had considered that the offer was a bad one, the majority could have rejected it. There was no coercion to accept a bad offer.

The Form Three Offer does have one important limitation, as do the Form One and Form Two Offers. It is designed to solve the holdout problem. As such, the Form Three Offer will not work unless the existing bonds, once stripped of their covenants, will be worth less than the new bonds offered in the exchange. The old 
bonds will still have a face amount of $\$ 1,000$, and it is possible that, even without protective covenants, they would be worth more than $\$ 800$ if the equityholders were to invest the additional $\$ 550$ in the new project. In that case, each bondholder would be confronted with a choice between holding onto the old bond or accepting a new one with a lower value, and the exchange offer would fail. If the bondholders could anticipate this outcome, presumably they would refuse to consent to the amendment of the indenture. What they should demand, in any event, is that any consent given in anticipation of an exchange be negated if the subsequent exchange offer did not succeed in attracting some prescribed percentage of the bonds. ${ }^{108}$

B. Disciplining the Holdout: The Prepackaged Bankruptcy Plan and the Form Three Offer Compared

Our suggested approach, the Form Three offer that precedes the tender with a bondholder vote, is vulnerable to one important criticism: because exchange offers to bondholders frequently fail, ${ }^{108}$ their real problem may be that they are not coercive enough.

Stripping the covenants from bonds may not be enough, for example, to deter vulture funds from holding out for opportunistic reasons. The managers of such funds may be willing to take risks, possibly because of the psychological effects of having bought the bonds, in the typical case, at very low prices. They may also be unconcerned about the feelings of distaste that more conventional members of the financial community may develop toward them. And they may conclude that, even with the covenants stripped, the expected return on the bonds is greater than the expected returns on the securities offered in exchange. In this setting, coercion would be ineffective because the issuer could not reduce the value of the bonds enough. Yet, other bondholders may feel compelled to accept the exchange offer, either because of the likely reduction in the bonds' liquidity once the covenants are removed, or because, in the absence of adequate disclosure, they overestimate the effect of the indenture amendments.

Finally, the managers of vulture funds may hold out because they believe that the issuer's management would not dare to exploit fully the discretion that the elimination of the covenants

\footnotetext{
${ }^{108}$ Such a condition would also protect against the potentially coercive effect of an offer by the firm of cash payments for consents.

100 See notes 21-22 (listing unsuccessful exchange and tender offers made in 1990).
} 
would give them, because the holdouts would still possess independent legal remedies not based on contract. For example, if the issuer paid massive dividends to equityholders and then defaulted on its bonds, the issuer's directors and management might be held liable to the holdout bondholders, either under corporate law for paying an unlawful dividend or under the law of fraudulent conveyances. ${ }^{110}$ These constraints are especially significant because the term of much high-yield debt is relatively short. As a result, the vulture fund may doubt that any distribution paid to shareholders on the eve of insolvency would survive judicial scrutiny. In short, the contractual right to exploit the bondholders, once all protective covenants are eliminated, is not equivalent to the legal right to do so.

It is thus puzzling that overleveraged issuers have not made greater use of other techniques scaling down their debt. The most obvious alternative is the prepackaged bankruptcy. ${ }^{111}$ In a "prepackaged" Chapter 11 reorganization, the corporation secures sufficient creditor consents to have a Chapter 11 plan confirmed by the bankruptcy court, then files its Chapter 11 petition, and seeks swift judicial approval of its proposed plan. If all goes well, the court confirms the plan in as little as two or three months. ${ }^{112}$ The attractiveness of this approach is that it requires the approval of only two-thirds of the bondholders in principal amount, plus a majority in number of those who vote on the plan. ${ }^{113}$ In contrast, the typical exchange offer today requires between ninety and ninety-

110 The Bankruptcy Code and two uniform state acts allow certain creditors and the trustee in bankruptcy to rescind any transfer or payment by a debtor that was made with an intent to defraud creditors, or that was made for less than a fair or reasonable equivalent at a time when the debtor was insolvent or expected to incur debts in the future beyond its ability to pay. See 11 USC $\$ \& 544,548$ (1988). Eleven states have enacted the Uniform Fraudulent Conveyance Act (UFCA), 7A ULA 427 (1985), and twenty-four have adopted the Uniform Fraudulent Transfer Act (UFTA), 7A ULA 639 (1985). The fraudulent conveyance issue has arisen frequently in the context of an LBO that later files for bankruptcy. See United States $v$ Gleneagles Investment Co., 565 F Supp 556 (M D Pa 1983), aff'd as United States v Tabor Court Realty, 803 F2d 1288 (3d Cir 1986) (applying the Pennsylvania UFCA); Wieboldt Stores v Schottenstein, 94 Bankr 488 (Bankr N D Ill 1988); In re Revco D.S., Inc., 118 Bankr 468 (Bankr N D Ohio 1990) (applying the Ohio UFCA). See generally James F. Queenan, Jr., The Collapsed Leveraged Buyout and the Trustee in Bankruptcy, 11 Cardozo L Rev 1 (1989).

${ }^{111}$ See 11 USC $\S 1126(b)$. For an overview, see sources cited in note 8.

112 Turnarounds \& Workouts, a trade publication, has prepared a chart showing nine prepackaged bankruptcies filed since 1986. Of these, seven were confirmed within five months, and of these seven, six were confirmed within three months. One was confirmed within five weeks. See Special Report: Prepackaged Bankruptcy Plans Attempted by Major Companies, 5 Turnarounds \& Workouts 3 (No 2, Feb 1, 1991).

"1s See 11 USC \$ 1126(c). 
five percent of all debtholders to accept the offer. ${ }^{114}$ If the requisite two-thirds of the bondholders approve the prepackaged bankruptcy, the holdout problem is automatically solved because the exchange of new securities for old is accomplished as a matter of law.

In fact, corporate issuers have increasingly turned to prepackaged bankruptcy plans ${ }^{115}$ - but usually only after a proposed exchange offer has first failed. ${ }^{116}$ The advantages of prepackaged filings are well-known and numerous. First, a two-thirds vote is a feasible goal. Second, the bondholders can vote prior to the filing of the petition, thereby reducing uncertainty. Third, the bankruptcy court can often quickly confirm the plan, sometimes within two or three months.117 Fourth, the costs of the procedure are low. ${ }^{118}$ Fifth, the corporation can more easily obtain new financing once a bankruptcy petition is filed. ${ }^{119}$ Sixth, there are tax advantages to effecting an exchange of debt securities in bankruptcy. ${ }^{120}$ And, lastly, prepackaged bankruptcy avoids what is know as the "LTV risk"-namely, the danger that on a subsequent bankruptcy of the debtor, the holder of the new securities received in an exchange offer will be deemed to have a valid bankruptcy claim only in the amount of the fair market value of the securities surrendered on the date of the exchange, rather than the face amount of the new securities. ${ }^{121}$

11 See Salomon Brothers Study at 1 (cited in note 4).

115 See id.

11 During 1990, Interco, Inc., Tracor Inc., The Southland Corp., and JPS Textile Group, Inc. turned to prepackaged bankruptcy plans after failing to secure the desired level of acceptance of their exchange offers. Id at 8, 11, 13.

117 See note 112.

118 Martin Whitman, a prominent "vulture fund" investor, estimates that a typical exchange offer costs "between $\$ 5$ million and $\$ 15$ million in direct costs." Henry, 5 Turnarounds \& Workouts at 2 (cited in note 8 ). These costs are lower in bankruptcy in large measure because the court must approve all fees paid by the debtor and the fees of advisors to the creditors. Indeed, this is one reason why industry professionals-both lawyers and investment bankers-may prefer an exchange offer to a prepackaged bankruptcy.

119 For a discussion of "debtor in possession" financings, see Mark C. Rohman and Michael A. Policano, Financing Chapter 11 Companies in the 1990s, 3 Continental Bank J Applied Corp Fin 96 (1990).

120 Under the Revenue Reconciliation Act of 1990 , corporate issuers that exchange new debt for old debt will normally have to realize cancellation of indebtedness income, because of the repeal of Internal Revenue Code $\$ 1275(a)(4)$ (1988). However, there is an exception for a debtor in bankruptcy, which does not realize such income. See 26 USC § 108(a) (1988). See Andrew N. Berg, Tax Changes: The Impact of the Budget Package on Debt Restructurings, 5 Insights 9 (No 2, Feb 1991) (recommending use of prepackaged bankruptcy alternative).

${ }^{121}$ See In re Chateaugay Corp., 109 Bankr 51 (Bankr S D NY 1990). Because Chateaugay Corp. is a subsidiary of the LTV Corporation, this danger is known as the "LTV risk." 
Given these advantages, why do issuers even bother with an exchange offer? The first answer appears to be the downside risk that arises if the prepackaged plan hits a snag and the firm thereby remains in bankruptcy for an extended period of time. In such delays, bankruptcy costs mount, and management's ability to run the firm is subject to judicial supervision. At present, the possibility of these snags is substantial: There are a number of significant and unresolved legal issues surrounding the operation of prepackaged bankruptcies, on which even prominent bankruptcy commentators have disagreed vigorously. ${ }^{122}$

A real-world example of how these uncertainties can disrupt even the best-laid plans of the issuer is the recent difficulty of The Southland Corporation in obtaining judicial confirmation of its prepackaged bankruptcy, after four earlier exchange offer solicitations had failed. ${ }^{123}$ Although Southland had secured a favorable two-thirds vote for the plan, dissident creditors attacked the adequacy of the procedures followed and the vote tabulation methods used by Southland, and the court ordered Southland to solicit a

While the decision has been appealed, its impact is to chill exchange offers, because the prospect of bankruptcy is always present in the case of a financially distressed company that is proposing a debt exchange offer. By accepting the exchange offer, the creditor sacrifices the difference between the face amount of the securities given up and the lesser fair market value of the securities received. The theory of Chateaugay is that the excess of the face amount of the new debt security over the market value of the old security on the date of the exchange (plus accreted interest) represents original issue discount and is disallowed in bankruptcy. Id at 56-58. See 11 USC $\$ 502$ (b)(2) (1988).

123 The greatest and most debated uncertainty concerns whetier the solicitation of votes on a prepackaged plan is governed exclusively by the federal securities laws or by some combination of those laws and the Bankruptcy Code. Under $\$ 1126(b)$ of the Bankruptcy Code, 11 USC $\S 1126(\mathrm{~b})$ (1988), the solicitation of consents before the filing of the bankruptcy petition must be in "compliance with any applicable bankruptcy law, rule or regulation governing the adequacy of disclosure in connection with such solicitation." This means that there must be compliance with the federal proxy rules if the debt security is listed on an exchange. Some commentators take the position that the Securities and Exchange Commission has exclusive jurisdiction, so that if it clears a proxy statement, there is no further role for the bankruptcy court. See Case and Harwood, Current Issues in Prepackaged Chapter 11 Plans (cited in note 8). Others contend that the bankruptcy court may still invalidate the solicitation if it finds that there have been material omissions or misstatements under the federal securities law standards; and that the bankruptcy court may establish its own standards with regard to procedural, timing, and vote tabulation issues. See also Chaim J. Fortgang and Thomas M. Mayer, Prepackaged Plans: Tyranny in Chapter 11 Reorganizations (unpublished paper prepared for Bankruptcy Symposium sponsored by the New York University of Law, the Annual Survey of American Law, and the John J. Galgay Fellowship Program, Apr 12, 1991) (on file with U Chi L Rev).

${ }^{123}$ See In re Southland Corporation, 124 Bankr at 211. See also Henry, 5 Turnarounds $\&$ Workouts 1 (cited in note 8). The Southland plan was ultimately confirmed after a second shareholder vote. See Tracking: Southland, 5 Turnarounds \& Workouts 4 (No 5, Mar 15, 1991). 
new vote. Some participants have suggested that the dispute in the Southland situation masked what was "a hold up by some dissidents aimed at collecting legal fees."124 Although we express no judgment on this issue, prepackaged bankruptcy plans are vulnerable in that small debtholders can delay judicial approval, even when they do not hold enough debt to impede an exchange offer. The problem is reminiscent of the nuisance derivative action brought by shareholders owning only a handful of shares.

Economic considerations may also impede the success of prepackaged bankruptcies. Today, the advisors who represent bondholders often charge substantial fees that a bankruptcy court would be unlikely to approve. ${ }^{125}$ Hence, the advisors' incentive is to achieve a pre-bankruptcy resolution to avoid substantially losing their fees.

Nevertheless, from a policy perspective, there is little need to dwell on these factors that impede prepackaged bankruptcies. Over time, legal uncertainties will be resolved or clarified, and the prepackaged bankruptcy may prove a superior vehicle by which to effect debt restructurings. Indeed, the prepackaged bankruptcy has one significant advantage over debt exchange offers and other consensual negotiations outside of bankruptcy: side payments and holdouts are not possible. Inherently, all within a class are treated equally and are bound by the class vote. Thus, there is not only greater fairness within the class, but also less capital market uncertainty and hence a lower cost of capital and greater efficiency.

Does this mean that prepackaged bankruptcies will gradually displace debt exchange and tender offers? We doubt it. For several reasons, we suspect that debt exchange and tender offers will continue to play a significant role in restructurings. First, issuers have not yet fully exploited the potential for coercive indenture amendments. Second, many issuers simply will not want to endure any form of bankruptcy because of its perceived stigma. Finally, many issuers may be ineligible to use the prepackaged bankruptcy technique because they are not insolvent, even though they would still like to retire deeply discounted outstanding debt claims against them. ${ }^{226}$ Whitman).

${ }^{125}$ Merrill Lynch would have received over $\$ 16$ million if Southland's out-of-court restructuring had been successful. See Schwimmer, Investment Dealers' Digest at 21 (cited in note 2). In-court restructurings typically pay much lower fees because of the need for, and difficulty of, judicial approval. Id.

128 Under this category, we would include transactions where a failure to effect a recapitalization would result in a "buoying-up" of the debt. See notes 85-89 and accompanying text. 
For the near future, the most likely scenario is that financially distressed issuers will simultaneously make an exchange offer and solicit a prepackaged bankruptcy. In particular, such an issuer may offer a marginally greater price in the exchange offer in order to elicit the bondholders' consent, but may also signal that it will file the prepackaged bankruptcy petition if a significant number of bondholders hold out. ${ }^{127}$ Such a tactic would both deter holdouts and minimize the risk of judicial supervision or delay in bankruptcy. Most significantly, it also justifies our focus on how to reform debt exchange offers by shifting control over coercive measures from the corporate issuer to the bondholders themselves. Again, as we stated above, the prepackaged bankruptcy has only one significant advantage over the Form Three Offer: it inherently assures equality within the class, because side payments and special deals are less possible in bankruptcy. Later, we will suggest that enlightened SEC regulation could largely achieve such equality for Form Three Offers. ${ }^{128}$

\section{Implementing the Form Three Offer}

There are three basic ways to implement our proposed solution to the coexisting prisoner's dilemma and holdout problems. In Part A, we consider certain self-help remedies available to bondholders-for instance, revising the indenture agreement to require Form Three exchange offers or acting collectively to resist unfavorable exchange offers. In Part $B$, we evaluate several methods by which a court could interpret existing indenture agreements to require Form Three Offers. In particular, we argue that the implied covenant of good faith and the requirement of good faith voting by bondholders might require corporations to propose restructurings through Form Three Offers. Finally, in Part C, we propose certain regulatory reforms under the Williams Act which could effectively implement our proposed solution.

\section{A. Self-Help Remedies}

1. Revising the indenture.

In the future, for newly issued obligations, unfair coercion can be foreclosed by altering the standard language of indentures. We

\footnotetext{
127 Such joint exchange offers and prepackaged solicitations have already appeared. See Case and Harwood, Current Issues in Prepackaged Chapter 11 Plans at 44 (cited in note 8).

128 See notes 179-86 and accompanying text.
} 
recognize that this may be easier said than done. Since standardized language enhances marketability, changes are made grudgingly. Moreover, the indenture is a long, detailed document. Prospective buyers of bonds focus on the creditworthiness of the issuer, the interest rate and duration of the debt, and, to a lesser degree, the major covenants. Even the major covenants' price effects tend to be small and difficult to detect. A change in the indenture to protect against the unfair use of exit consents to coerce an exchange might turn out to be important, but at the time of issuance may have no discernible effect on the price at which the obligation can be sold. Thus, issuers may have no incentive to give up the power that is available to them under the present language.

At the same time, debt these days is sold mostly to large institutions with sophisticated staffs. If buyers were to request a change in the language relating to amendment to prevent pernicious coercion, we believe many issuers would accede to such a request. The needed protection could be provided simply, with only a small change in the existing standard language. Standard language currently denies a vote to any obligations "owned" by the issuer. ${ }^{128}$ New language could deny the vote to obligations that have been tendered to the issuer, unless the tender offer is open to holders that vote against the proposed amendment; void any votes for which the issuer has paid cash or any other consideration; or void the consent if the exchange offer failed. ${ }^{130}$ Such a change should have no adverse effect on the marketability of the bonds, and might even make obligations with the new language more marketable.

Still, many issuers may resist the desired language and may even be willing to incur a market penalty in the form of higher interest rates in order to preserve their ability to make coercive tender offers that avoid bankruptcy. ${ }^{131}$ Behind this resistance to

120 See notes $147-49$ and accompanying text.

130 To make clear that a Form Three Offer would be permissible, it could be stated that the voting prohibition is not intended to void any vote in connection with a tender offer that is contingent on the outcome of the vote.

${ }^{131}$ A 1991 survey by Institutional Investor asked corporate chief financial officers whether, if they were to offer bonds in the next six months, they would attach strong covenants, weaker covenants providing only "some protection," or no covenants. Nine percent said they would offer strong covenants, $43.8 \%$ said they would offer only "some protection," and $47.2 \%$ said they would offer no covenants. CFO Forum: Is Anyone Paying Any Heed to Bondholders?, Institutional Investor 123 (Feb 1991). Such a finding suggests strong managerial resistance to stronger covenants or to other changes that would restrict managerial discretion. 
stronger protections for bondholders may lie the pervasive phenomenon of managerial risk aversion. Corporate management has more reason to fear bankruptcy than do shareholders, who typically hold diversified portfolios. Management may resist including bond covenants and other provisions that would reduce the firm's cost of capital, even though such provisions would be in the interest of their shareholders. Hence, we are unable to say that model indenture provisions will alone solve the problem of unfair coercion in debt exchange offers, and we acknowledge that the sophisticated counsel who work in this field probably were well aware before reading this Article that such protective provisions could be designed..$^{132}$

\section{Other market mechanisms.}

Because the coercive effect of an exit consent depends on an inability of debtholders to enter into an "enforceable agreement," debtholders may be able to protect themselves, or be protected by others, in several ways. First, if the debtholders are few enough, and if they are "repeat players," they may simply communicate with each other and agree not to tender into the exchange offer. ${ }^{133}$ Of course, they may instead agree that the offer is benign rather than pernicious and that they should tender. ${ }^{134}$

Second, if dispersion of ownership lowers the value of debt obligations, one would expect individuals or entities to acquire the obligations so as to overcome the dispersion problem. There is evidence that this phenomenon has in fact occurred, especially among

${ }^{135}$ We also note that some sophisticated institutional investors have recently petitioned the SEC for regulatory reform of the exit consent problem, although they more than anyone else were in a position to demand and draft new indenture language. See note 182 .

1ss See Pat Widder, Debt Orchestrates '90s Theme: "Deals Done Again", Chi Trib C1 (Sep 6, 1990) (quoting an investment manager as saying that "holders of junk know each other and are getting to know each other better" "); Schifrin, Enough Already! Forbes at 132 (cited in note 20) (bondholders organizing "through an association that collects and distributes information about defaults, and passes along advice on how to deal with exchange offers"; informal committees of bondholders organized by an investment adviser who is paid a fee).

134 This was the case in Katz, $508 \mathrm{A2d}$ at $878 \mathrm{n}$ 6. Specifically, one debt issue involved in the case was $85 \%$ owned by four financial institutions, with one investment banker owning $55 \%$; while another issue was $69.1 \%$ owned by four institutions; still another issue was $85 \%$ owned by five institutions; and the remaining issue was approximately $45 \%$ owned by two banks. Presumably the exchange offer was approved in advance by the debtholders, which explains why the court seems to have assumed that there was no coercion (true, as to the major investors) or a benign effort to solve the holdout problem (as to the other holders). 
vulture funds. ${ }^{135}$ Still, these more sophisticated bondholders are exactly the parties who may seek to take advantage of the other bondholders by either holding out or demanding a side payment. Thus, solving one problem may exacerbate another.

If self-help and market mechanisms were likely to solve the problem, there would be little need for judicial intervention. But self-help, even if feasible, does involve some costs. Market mechanisms are also costly to implement and, because the purchasers who overcome the dispersion problem must be rewarded for their efforts, they will not fully compensate the original dispersed owners. The result will be an impediment to the initial issuance of debt obligations to the public, with a corresponding increase in cost for issuers. ${ }^{136}$ The optimal remedy then should be a minimally intrusive one that facilitates self-help measures, but assures that the bondholders' choice is not distorted by managerial pressure. We restate below why we think our proposals satisfy these criteria.

\section{B. Construing the Indenture Agreement}

The basic claims and rights of bondholders are specified in detail in the bond indenture. In settling disputes over bondholder claims and rights, courts have generally looked to the language of the indenture and applied traditional techniques for interpreting contracts, rather than invoking judicially developed doctrines, such as the doctrine of fiduciary obligation. ${ }^{137}$ As the American Bar

135 See Peterson, LA Times at D1 (cited in note 2) ("a growing number of "vulture firms' are snatching up distressed bonds at garage-sale prices"); Schifrin, Pay Up, Forbes 74 (cited in note 23). See also Paul Richter, "Debt Raiders" See Bull Market in Bankruptcies, LA Times D1 (Oct 21, 1990).

${ }^{136}$ Issuers can avoid this cost by providing protection in the debt contract against coercive offers. However, the language of publicly issued debt covenants changes slowly, if at all, even after events seem to have established a need for new language. For example, in Morgan Stanley \& Co. v Archer Daniels Midland Co., 570 F Supp 1529, 1532-34 (S D NY 1983), Morgan Stanley \& Co., a sophisticated and economically powerful investment banking firm, complained that the issuer of certain debt obligations had redeemed those obligations in violation of the language of the indenture and its expectations as an investor. The court denied Morgan Stanley's motion for summary judgment. Yet investors like Morgan Stanley continued to accept the same language in obligations issued after the decision. Presumably some issuers did not expect to take advantage of that language in the manner about which Morgan Stanley complained. Yet they may have paid a price for the opportunity to do so. Some repeat issuers might be subject to informal sanctions, as was apparently true for Archer Daniels, the defendant in the case. See Richard S. Wilson and Frank J. Fabozzi, The New Corporate Bond Market 188 (Probus, 1990) (Archer Daniels's next bond issue "was not well received" and a subsequent issue contained strong investor protection.).

237 This statement is valid for the problems considered in this Article. It is worth noting, however, that the claims of debtholders are substantially affected by bankruptcy law and, in the case of publicly issued debt, by the Trust Indenture Act of 1939, 15 USC § 77aaa (1988). 
Foundation has stated:

[T] he rights of holders of debt securities are largely a matter of contract. There is no governing body of statutory or common law that protects the holder against harmful acts by the debtor except in the most extreme situations. Short of bankruptcy, the debt securityholder can do nothing to protect himself against actions of the borrower which jeopardize its ability to pay the debt unless he takes a mortgage or other collateral or establishes his rights through contractual provisions set forth in the ... indenture. ${ }^{138}$

Although courts have uniformly held that directors of a corporation do not owe a fiduciary duty to bondholders, ${ }^{138}$ there is an important, but ill-defined, exception to this general rule, which arises when the corporation becomes insolvent. ${ }^{140}$ The source of this potential fiduciary duty to debtholders has been traced by some courts to the "trust fund doctrine,"141 which they interpret to hold "that all of the assets of the corporation, immediately on its becoming insolvent, become a trust fund for the benefit of all of its creditors." "142 The case law is ambiguous as to what defines insolvency for purposes of this fiduciary duty: a balance sheet test, an actual inability to pay debts as they mature, or the corporation's ceasing to operate as a going concern. ${ }^{143}$ It is even cloudier as to whether the "springing" fiduciary duty that arises on insolvency (however defined) brings into play the same open-ended fiduciary

${ }^{238}$ American Bar Foundation, Commentaries on Model Debenture Indentures at 2 (cited in note 53). This passage is quoted and relied upon in Sharon Steel Corporation v Chase Manhattan Bank, N.A., 691 F2d 1039, 1049 (2d Cir 1982). See also Simons v Cogan, 549 A2d 300 (Del Sup Ct 1987); Comment, Debenture Holders and the Indenture Trustee: Controlling Managerial Discretion in the Solvent Enterprise, 11 Harv J L \& Pub Pol 461, 477-81 (1988); William W. Bratton, Jr., The Interpretation of Contracts Governing Corporate Debt Relationships, 5 Cardozo L Rev 371, 374 (1984)(arguing for a "neoclassical" approach, in which judges attempt to "protect the particular parties' expectations").

139 See Simons, 549 A2d at 304.

${ }^{240}$ Simons v Cogan, 542 A2d 785, 788 (Del Chanc 1987).

${ }_{141}$ In re MortgageAmerica Corp., 714 F2d 1266, 1268-70 (5th Cir 1983).

${ }^{243}$ Saracco Tank \& Welding Co. v Platz, 65 Cal App 2d 306, 150 P2d 918, 923 (1944) (quoting William M. Fletcher, 15 Fletcher's Cyclopedia of Corporations $\$ 7369$ at 59 (Callaghan, 1938)).

14s In MortgageAmerica, the court framed the test as follows: "Those who control an insolvent corporation that can no longer be considered a true going concern are ... 'charged with the duty of seeing that the creditors of a corporation [are] either paid in full or they are paid pro rata out of the funds received from the assets of the corporation.' " $714 \mathrm{~F} 2 \mathrm{~d}$ at 1271 (quoting Waggoner v Herring-Showers Lumber Co., 120 Tex 605, 615, 40 SW2d 1, 5 (1931)). 
duties of care and loyalty that are owed to stockholders (in normal times), or whether the duty should be more narrowly construed simply to forbid the directors from diverting corporate assets for the benefit of themselves or preferred creditors. ${ }^{144}$ New York decisions in this area seem substantially more inclined to impose liability on directors than those of Delaware. ${ }^{145}$

These cases suggest that corporate officials of an insolvent firm do owe some "extracontractual" duties beyond simply observing the terms of the bondholders' contract, but the courts have applied these duties largely only to preclude transactions that would resemble a voidable preference in bankruptcy or a fraudulent conveyance. These decisions do not yet support any general affirmative duty to bondholders that might require the directors to obtain the best possible substantive terms (or even fair terms) for the bondholders in any recapitalization. Still, given the existence of some extracontractual duties owed to the bondholders once the issuer becomes insolvent, it might fairly be argued that the directors have an obligation to adopt fair procedures that permit the bondholders to exercise their own uncoerced judgment-in short, the Form Three Offer. Although such a doctrinal development is possible, it would require a judicial leap, and thus we discuss possible narrower theories to this same end.

\section{Construing "ownership" of the bonds.}

Most provisions in bond indentures may be amended with the consent of at least a majority (generally, however, two-thirds) in face amount of the "outstanding" bonds. ${ }^{146}$ For purposes of voting on amendments, the almost universally used indenture language provides that "outstanding" bonds do not include those "owned" by the obligor. ${ }^{147}$ This is sometimes referred to as a "sterilization"

14 For this narrower interpretation, see Rosebud Corp. v Boggio, 39 Colo App 84, 90, 561 P2d 367, 372 (1977); Fountain v Burke, $160 \mathrm{Ga}$ App 262, 264, 287 SE2d 39, 41 (1982); Bortner v J.C. Lieb Co., 146 Md 530, 542, 126 A 890, 895 (1924) (all prohibiting repayment of debts or claims to corporate officers or directors); Wilkinson $v$ Bauerle, $41 \mathrm{NJ}$ Eq 635, 644, 7 A 514, 518 (1886).

${ }_{145}$ Compare New York Credit Men's Adjustment Bureau, Inc. v Weiss, 304 NY 547, 110 NE2d 397 (1953), and Clarkson Co., Ltd. v Shaheen, 660 F2d 506, 513 (2d Cir 1981), with Asmussen v Quaker City Corp., 156 A 180 (Del Chanc 1931).

14. American Bar Foundation, Commentaries on Model Debenture Indentures at 41-42, 305 (cited in note 53). Note, however, that the core provisions relating to principal, interest, and maturity may not be amended. See note 54 .

147 See American Bar Foundation, Commentaries on Model Debenture Indentures at 42 (cited in note 53); American Bar Association, Model Simplified Indenture, 38 Bus Law at 763 (cited in note 53). See also Katz, 508 A2d 873. 
rule. The contract interpretation issue when there is a challenge to the use of the exit consent procedure turns largely on the meaning of the word "owned" in the sterilization provision.

In the exit consent procedure, essentially, the owner of the bond votes by giving consent to the amendment. In a literal sense, at the time the amendment is voted upon, the obligor does not "own" the bonds; they are still owned by the person who has tendered them. It is true that the bonds are voted in a manner consistent with the wishes of the obligor, and that the obligor may have constrained the holder's voting choice by creating a prisoner's dilemma, but the indenture language is narrow. It says "owned," not "owned or controlled" or some other such broad language. It would be possible, of course, to devise language that would clearly foreclose or limit the exit consent procedure. ${ }^{148}$ But we are aware of no indenture that contains such language. There are, of course, substantial advantages to this literal, or "plain-meaning," approach: certainty and consistency, which can be important for market efficiency. ${ }^{149}$

A broader interpretation of "ownership" would not frustrate the presumed intent of the parties. In an exchange offer with exit consent, bonds are tendered to the obligor accompanied by the consent. They are not redeemed by the obligor at the time of the tender, or at the time of the effectuation of the consent, but the parties' expectation is that some or all of the bonds will be redeemed in due course. It would not be a great stretch of the word "owned" to treat bonds held by the obligor in this setting as bonds "owned" by the obligor. Such an interpretation might not even require use of a subterfuge concept like "constructive" ownership to avoid the plain meaning of the sterilization provision, but if such a concept might help in justifying the result, there is certainly a strong tradition in the law for providing that help.

The fact that "ownership" might be read broadly does not, however, mean that it must be. One must ask whether such an in-

${ }^{148}$ See text accompanying notes 128-30.

148 Compare Sharon Steel Corporation, 691 F2d at 1039, where the court pointed to the need for certainty in the capital markets, and concluded that interpretation of boilerplate indenture provisions should be a matter of law for the court and not a matter of fact for the jury or other trier of fact. See Bratton, 5 Cardozo L Rev at 401-02 (cited in note 138).

However, an interpretation of the sterilization clause to exclude pernicious exchange offers with exit consents might not seriously undercut the goals of certainty and consistency. It would not depend on the particular expectations of individual lenders and borrowers. Most bonds are governed by New York law. Thus, if the New York courts adopted an interpretation precluding pernicious offers, uniformity would be achieved. It is hard to see how an initial decision to that effect could cause surprise or consternation in the bond market. 
terpretation produces an appealing result, or whether that interpretation seems likely to be consistent with the intent of the parties. In responding to this inquiry, we can begin with the apparent purpose of the sterilization clause: ensuring that bonds are voted in the interest of the obligees rather than in the interests of the obligor. In the case of an exit consent accompanying a tender into an exchange offer, if the exit consent is used for a pernicious purpose, the vote effectively serves the interests of the obligor at the expense of the obligees. In such a setting, the exit consent falls within a general category of actions that the sterilization clause is designed to protect against.

On the other hand, exit consents can also be used for benign purposes; interpreting "ownership" to cover bonds held for redemption with an exit consent would preclude that benign use. What is particularly troublesome is that such an interpretation might preclude the use of exit consents even in the case of a Form Three Offer, and one should recall that a Form Three Offer (unaccompanied by vote buying) cannot be used perniciously. ${ }^{150}$

One could, of course, torture the interpretation of "ownership" to produce a rule allowing the use of exit consents for benign, but not for pernicious, purposes; or to produce a rule permitting Form Three Offers, but not Form One or Form Two Offers. Although various distinctions can be made in terms of who has possession of the bonds at the time of the vote, most of these distinctions collapse under close analysis. Ultimately, creative construction of this kind trivializes the legitimate role of interpretation. It is better, we think, to generate a rule consistent with good results by invoking one of the two judicial constructs described below: the implied covenant of good faith and fair dealing or the requirement of good faith voting.

2. The implied covenant of good faith.

Today, all contracts are interpreted to contain an implied covenant of good faith. ${ }^{151}$ Basically, this means that "there is an im-

${ }^{180}$ That is, Form Three Offers unaccompanied by payments for the vote or consent cannot distort bondholder choice. A significant payment for the vote, however, does penalize those who wish to vote "no" and gives rise to the prisoner's dilemma problem. To see this, consider a case of a bond trading at $\$ 700$ where the issuer offers $\$ 300$ for the vote and $\$ 401$ for the bond, but the amendment will reduce the bond's value to $\$ 300$. A substantial payment for the vote can make the Form Three Offer effectively equivalent to a Form Two Offer.

${ }^{161}$ See Restatement (Second) of Contracts $\S 205$ (1981). See also Steven J. Burton, Breach of Contract and the Common Law Duty to Perform in Good Faith, 94 Harv L Rev 369 (1980). 
plied covenant that neither party shall do anything which will have the effect of destroying or injuring the right of the other party to receive the fruits of the contract ...."152 What are the "fruits of the contract" in the case of a bond indenture? It is too much to argue that all the protective covenants in the indenture constitute such fruits because clearly the indenture contemplates that they can be amended. It might be argued that any amendment of the indenture contemplated by the parties at the time of contracting should offer mutual advantages and should not be deliberately intended to make all non-consenting bondholders worse off. But again, this proposed interpretation is too vague and would also bar Form Three Offers.

A more focused definition of the implied covenant of good faith has been given by the Chancellor of Delaware in a case dealing precisely with coercive debt exchange offers. In Katz v Oak Industries, Inc., ${ }^{163}$ Chancellor Allen supplied the following test for measuring the implied covenant of good faith:

[I]s it clear from what was expressly agreed upon that the parties who negotiated the express terms of the contract would have agreed to proscribe the act later complained of as a breach of the implied covenant of good faith-had they thought to negotiate with respect to that matter. ${ }^{154}$

In short, can one identify some express term in the contract that is rendered meaningless or illusory by the challenged conduct so that one cannot believe that rational parties would negotiate the express term without also wanting to proscribe the challenged conduct (if they had focused on it)? Although the Katz decision upheld the exchange offer at issue, this mode of analysis may supply bondholders with a powerful argument. Would bondholders that had required the issuer to agree that it would not vote any shares it "owned" (as the standard indenture provides) have permitted the issuer to vote shares beneficially owned by it but still legally

102 Kirke La Shelle Co. v Paul Armstrong Co., 263 NY 79, 87, 188 NE 163, 167 (1933). For a recent use of the "fruits of the agreement" language, see Metropolitan Life Insurance Co. $v$ RJR Nabisco, Inc., 716 F Supp 1504, 1518-19 (S D NY 1989), where the court refused to provide additional protection that would, in its view, have required not just shoring up an existing covenant but writing in a new one, "an additional benefit for which [the plaintiffs] did not bargain."

${ }^{183} \mathrm{Katz}, 508 \mathrm{A2d}$ at 873. See also Kass v Eastern Airlines, Inc., CA Nos 8700, 8701 and 8711, slip op (Del Chanc, Nov 14, 1986) (bondholder votes purchased in return for cash or ticket discounts).

1st Katz, $508 \mathrm{A2d}$ at 880 . 
held of record by a tendering bondholder? ${ }^{105}$ We think not, because it exposes them to the prisoner's dilemma. ${ }^{156} \mathrm{We}$ do not see

${ }^{135}$ We recognize that in $\mathrm{Katz}$, Chancellor Allen purported to explain why the standard indenture restriction on "the voting of treasury securities" did not bar vote buying by the issuer. $508 \mathrm{~A} 2 \mathrm{~d}$ at 881 . He wrote:

The evident purpose of the restriction ... is to afford protection against the issuer voting as a bondholder in favor of modifications that would benefit it as issuer, even though such changes would be detrimental to bondholders. But the linking of the exchange offer and the consent solicitation does not involve the risk that bondholder interests will be affected by a vote involving anyone with a financial interest in the subject of the vote other than a bondholder's interest.

Id. His reasoning was that the "proposed consents [will] be granted or withheld only by those with a financial interest to maximize the return on their investment in Oak's bonds ... [and] the incentive to consent is equally available to all members of each class of bondholders." Id. We disagree with this analysis because its logic denies bondholders the ability to negotiate with the issuer effectively. See note 150 .

${ }_{158}$ The problem with Chancellor Allen's analysis, in our view, is that it ignores the prisoner's dilemma problem, as it applies to the Form Two Offer. See notes 67-68 and accompanying text. Suppose a majority of the bondholders actually believe that their bonds will be worth $\$ 800$ (either based on their intrinsic value or what they believe the issuer's next offer will be if they reject its first offer). The issuer, however, has offered only $\$ 710$ plus a $\$ 40$ payment for their vote. The effect of the amendments will be to reduce the value of the bonds to $\$ 700$, which had previously traded in a thin market at around $\$ 725$. Assuming the bondholders cannot communicate, their decision matrix looks like this:

Your Choice

$\begin{array}{cc}\begin{array}{c}\text { Don't Consent } \\ \text { and Tender }\end{array} & \begin{array}{c}\text { Consent } \\ \text { and Tender }\end{array}\end{array}$

Don't Consent and Tender $\$ 800$

$\$ 800$

Sufficient

Others'

Choice

$\$ 800$

Consent

and Tender

$\$ 700$

$\$ 750$

Here, it is rational to consent and tender, because the payoff from the combination of $\$ 800$ and $\$ 750$ obviously exceeds the payoff from the combination of $\$ 800$ and $\$ 700$. Thus, as long as one suspects that fellow bondholders may consent and tender, it is rational to do likewise. Chancellor Allen's analysis focuses only on the danger that an issuer may buy $51 \%$ of the bonds in order to strip the covenants. Yet, vote payments may also be used to create the above decision matrix under which it is individually rational to do what a majority of the bondholders would collectively consider to be irrational. We suspect that Form Two Offers, such as the foregoing, which often involve a modest tender premium and a significant vote payment, may be used particularly when the issuer decides to obtain indenture amendments to facilitate a specific transaction (such as a dividend). See note 64 .

Absent vote buying, a bondholder that believes that the issuer will respond to a negative vote by making a higher offer can vote no; with vote buying, it must factor into its analysis the behavior of the other bondholders (both in voting and tendering). Our view of the standard indenture clause's purpose is that it was intended to give bondholders an unconstrained choice in voting decisions that does not require them to vote contrary to their best judgment because of their estimates of how their fellow holders would vote.

Despite our objections to the test framed in Katz, we recognize that the exchange offer in that case was probably benign, given the premium offered, the low number of bondhold- 
any plausible reason why rational parties would cover the first situation (legal ownership) and not the second (beneficial ownership).

Still, under this interpretation, is a Form Three Offer also forbidden? Seemingly not, because, in the Form Three Offer, the vote precedes the tender and is the product of the undisturbed choice of the bondholders. Even under the expansive definition given "beneficial ownership" under the federal securities laws, this distinction may stand up. The federal securities laws define one to be a "beneficial owner" of a security if one has or shares "voting power" or "investment power" over the security. ${ }^{167}$ Today, under SEC Rule 13d-3, the corporate issuer is probably deemed a beneficial holder of an equity security once it receives a proxy or consent or the bonds are tendered into the offer so that the issuer effectively obtains the power to purchase them (and thus to "dispose" of them); this conclusion holds whether the offer is a Form One, Two, or Three Offer. Yet, uniquely, a Form Three Offer could be designed so that the issuer would not be the beneficial holder of the bonds under this standard at the time the consents are solicited and voted. Because the vote precedes the tender, it is possible to give the proxies to an independent third party, such as a bank or trust company. Then, if the bonds could not be tendered until after the vote was taken, the issuer would lack both voting power and any arguable investment power over the bonds at the time of the vote, so it should not be deemed their "beneficial owner." We recognize that contractual provisions in an indenture need not be construed in light of definitions in the federal securities laws, but the policies underlying these rules are uniquely relevant to the context of exchange and tender offers. In short, even under the most expansive definition of "ownership," a Form Three Offer need not be treated the same as a Form One or Form Two Offer.

In the last analysis, the role of the implied covenant of good faith is to protect the flanks of a contract's express provisions. Here, the express provision in the indenture "sterilizes" the issuer from voting its own bonds in its self-interest. Once the parties agree to such a provision, it seems likely that they would have

ers (which could therefore have successfully resisted), and the fact that new funds were being brought into the firm by a third party.

${ }_{187}$ See Rules 13d-3(a) and 14d-1(b)(4), 17 CFR $\S \S 240.13 d-3(a)$ and 240.14d-1(b)4 (1991). However, under the last clause of Rule 14d-1(b)(4), mere voting power does not make one a beneficial owner for purposes of the tender offer rules. "Voting power" is defined to include "the power to vote, or to direct the voting of such security," and "investment power" is defined to include "the power to dispose, or to direct the disposition of such security." See Rule 13d-3(a). 
wanted to protect the flanks of that provision from an evasion under which the issuer acquired "beneficial ownership" before it acquired record ownership. But the bondholders' decision to vote for the tender or exchange offer by approving the indenture amendments is not similarly compromised; the issuer should be seen as acquiring a beneficial interest in the bonds only after bondholders vote their acceptance of its offer. If this conclusion is accepted, Form Three Offers stand on a different footing from Form One and Two Offers.

\section{Good faith voting by debtholders.}

Another legal theory that might be used to attack coercive exchange offers is based not on an obligation of the corporation to the debtholders but rather on an obligation of the debtholders to each other. The theory is simply that the debtholders must vote in good faith. The leading case is an old one, Hackettstown National Bank v D.G. Yuengling Brewing Co. ${ }^{158}$ The plaintiff in that case was a holder of a minority of the bonds of a corporation that had defaulted on its obligation to pay interest. The principal shareholder, Yuengling, formed an alliance with a man named Betz, who bought enough bonds so that, together with the bond holdings of Yuengling and his friends and relatives, they had the three-fourths in value necessary to amend the indenture to postpone the obligation to pay interest. Yuengling had agreed personally to repay Betz's investment, with adequate interest. Although the language of the indenture allowed amendment by a three-fourths vote, without qualification, the court nullified the amendment, saying that a vote that is "made collusively ... for the purpose of defeating the remedy of the minority, and not in the exercise of an honest discretion in the general interest, is not a consent within the meaning of the [indenture]." ${ }^{159}$ In what may seem to be a questionable reliance on the fiduciary obligation of partners to one another, the court stated that "[c]ommunity of interest, whether in"the case of partners or security holders, creates mutual obligation, and im-

${ }^{168}$ Hackettstown Natl Bank v D.G. Yuengling Brewing Co., 74 F 110 (2d Cir 1896). The case was featured in a leading treatise on bonds published in 1937. Ralph A. McClelland and Frederick S. Fisher, Jr., The Law of Corporate Mortgage Bond Issues 824 (Callaghan, 1937), (reprinted by William S. Hein, 1983). The case also "figured in prominent legal corporate finance texts of the 1930s." Roe, 97 Yale $\mathrm{L} J$ at 252 (cited in note 24).

150 Hackettstown, $74 \mathrm{~F}$ at 112. 
poses upon all persons occupying that position the duty of acting in good faith toward the interests of their associates."180

The collusion and blatant bad faith in Hackettstown are not present when debtholders execute an exit consent. Yet the idea that bondholders should act toward one another in good faith hardly seems surprising. The question would remain, however, of how to interpret the requirement of "good faith" in the context of an exchange offer with exit consent. To answer this question, think of the prisoner's dilemma. Each prisoner votes knowing that he or she is imposing harm on the other. Each acts in contravention of the common good. From one perspective, this is "bad faith"; from another, it is acting in one's rational self-interest. While we do not predict that courts will invalidate the use of exit consents on bad faith grounds, such a result would not astonish us. In the case of a pernicious use of an exit consent strategy, each debtholder executes a consent believing that its action is contrary to the common good. It is hard to see how a judicially imposed prohibition on such action would undercut the contract. It is hard to imagine that any parties to a contract, if confronted at the negotiation stage with a rule adopting such a prohibition, would reject it.

A more troublesome concern arises from the fact that the exit consent strategy may be used for benign purposes, namely, to solve the holdout problem. A court might be reluctant to adopt a rule that would either be overbroad (rejecting any use of exit consents, even if benign) or would require a perhaps difficult determination of whether a particular offer was benign or pernicious. But there is an easy answer to this concern. Recall that the holdout problem can be solved by any of the three forms of offer. Form One and Form Two Offers both can be used for benign or for pernicious purposes, while Form Three Offers can only be used to accomplish the benign objective. Thus a court might conclude that even though a Form One or Form Two Offer may serve a benign objective, because those offers can also serve a pernicious objective, and because there is another way to achieve the benign objective, all Form One and Form Two Offers should be "presumed" pernicious. Accordingly, any votes (consents) in response to them would be "in bad faith."

180 Id. Compare Hogg v Hoag, 107 F 807, 818 (Cir Ct S D NY 1901), which, in a case involving a dispute that was essentially among equityholders, cited Hackettstown to support the following statement:

But the trust provision by which the majority in interest of certificate holders were to control its management is not to be construed as permitting an arbitrary and inequitable exercise of the power of the majority towards the minority. Such provisions are enforceable only when the majority exercises an honest discretion in the interests of all. 
The same result might be reached without use of ideas such as "presumption" or "bad faith." Still, if those familiar legal phrases or constructs are comforting to some, no harm comes from using them.

\section{Regulatory Reform}

Tender offers, including exchange offers, are regulated on the federal level by the Williams Act. ${ }^{101}$ Most of the mechanical rules of the Williams Act are set forth in $\S 14(\mathrm{~d})$ of the Securities Exchange Act of 1934, while its other relevant section, § 14(e), proclaims a broad antifraud rule. Section 14(d) applies by its terms only to tender offers for the equity securities of "reporting" companies, ${ }^{162}$ while $\S 14(\mathrm{e})$ applies to all tender offers, including offers for debt securities and securities of non-reporting companies. ${ }^{163}$ As a result, the rules adopted by the SEC under $\$ 14(\mathrm{~d})$ do not apply on their face to debt tender offers.

Three important tender offer rules fall under this heading: (1) the withdrawal rule, (2) the proration rule, and (3) the "best price" rule. First, under $\S 14(d)(5)$, tendering shareholders have the right to withdraw shares tendered to a bidder "until the expiration of seven days after the time definitive copies of the offer . . . are first published or sent or given to securities holders." 184 As extended by Rule $14 \mathrm{~d}-7,{ }^{165}$ a shareholder may withdraw tendered shares for the life of the tender offer. As a practical matter, this means that if a rival bid is made, the tendering shareholder may withdraw and accept the higher bid, at least until the point at which the first bidder accepts the shares. In contrast, in debt tender offers, it is customary to provide only limited withdrawal rights and sometimes none at all. ${ }^{186}$ The effect is to limit the ability of holdouts or rival

161 The principal sections of the Williams Act relevant to this Article's analysis are $\S \S 14(\mathrm{~d})$ and 14(e). See Securities Exchange Act of 1934, §§ 14(d) and 14(e), 15 USC $\S \S 78(n)(d)$ and $78(n)(e)(1988)$.

102 The Williams Act, $\S 14(\mathrm{~d})$, applies to tender offers for "any class of equity security which is registered pursuant to Section 12 of this title" and to equity securities of certain exempt issuers, such as insurance companies and mutual funds. It also applies only to tender offers for more than $5 \%$ of the class. 15 USC $\S 78(n)(d)$. In addition, some of its subsections specifically refer to "equity securities." See 15 USC \& 78(n)(d)(6).

${ }_{16 s}$ The Williams Act, § 14(e), which largely parallels SEC Rule 10b-5, refers to "fraudulent, deceptive or manipulative acts or practices, in connection with any tender offer or request or invitation for tenders, or any solicitation of security holders in opposition to or in favor of any such offer, request, or invitation." 15 USC $\S 78(n)(e)$.

166 15 USC \& 78(n)(d)(5).

18517 CFR § 240.14d-7 (1991).

186 See Note, 91 Colum $\mathrm{L}$ Rev at 852 (cited in note 5) (citing issuer exchange offer to Western Union bondholders in which no right of withdrawal was provided). 
bidders to persuade tendering bondholders to reconsider their decision and withdraw.

A more important right is the proration right afforded by $\S 14(d)(6)$, which requires that in the event a partial offer is oversubscribed, the issuer must take up the excess securities "as nearly as may be pro rata." ${ }^{167}$ Thus, if a bid is made for 50 percent of a corporation's stock, and 100 percent is tendered, every shareholder will have half its shares accepted and half returned. This rule of equal treatment, which SEC Rule 14d-8 ${ }^{168}$ now extends for the life of the offer, reduces the pressure to tender. However, by its terms, Rule $14 \mathrm{~d}-8$ is inapplicable to debt tender offers. ${ }^{169}$ Thus, an issuer can structure its offer so that it makes a partial bid (say for 80 percent of the debt securities in the class) and announce that it will accept these bonds on a "first come, first served" basis. The result is that bondholders that do not tender at or near the outset of the offer will face the prospect that the offer will be oversubscribed or at least that a disproportionately high percentage of their securities will be returned. This means not only that they will receive less than other bondholders, but that they will thereafter hold securities with reduced protections as the result of the adverse indenture amendments that the issuer also likely sought. Today, issuers are exploiting this technique in debt tender offers by providing for full proration for only a limited period and then first come, first served acceptance thereafter. ${ }^{170}$ Not only does this tactic reduce the time bondholders have to evaluate the offer, but it may make bondholders wary of advice from those urging them to hold out, who might in fact have an adverse interest. ${ }^{171}$

Finally, § 14(d)(7) sets forth the Williams Act's "best price" rule: If the tender offer's terms are varied or increased, the bidder must pay "the increased consideration to each security holder whose securities are taken up and paid for pursuant to the offer." ${ }^{172}$ Another SEC rule, Rule 10b-13, prohibits the bidder from

${ }^{2 e 7} 15$ USC $\S 78(n)(d)(6)$. This section applies by its terms only to shares deposited within the first ten days after the offer is commenced. But see note 176 .

16s 17 CFR § 240.14d-8 (1991).

${ }^{168}$ Rule $14 d-8$ specifically refers to "equity securities."

170 See Note, 91 Colum L Rev at 851-52 (cited in note 5) (discussing Greyhound and other debt tender offers using this technique).

${ }^{171}$ For example, after encouraging others to hold out, the adviser can itself tender and thereby decrease the percentage of its bonds that would be returned by virtue of proration.

${ }^{172}$ See 15 USC $\$ 78 \mathrm{n}$ (d)(7) (1982). This statutory rule is amplified by Rule 14d-10, which states in subsection (a)(2) that: "The consideration paid to any security holder pursuant to the tender offer is the highest consideration paid to any other security holder during such tender offer." See 17 CFR § 240.14d-10 (1991). 
purchasing outside the tender offer during its pendency, thus protecting the flanks of the "best price" rule against evasion through privately negotiated purchases. ${ }^{173}$ But again, Rule $10 \mathrm{~b}-13$ applies by its terms only to equity securities. Hence, a bidder may tender at a price of, say, $\$ 500$ per bond, but then pay $\$ 600$ in a privately negotiated purchase for a "swing" block that just gives it sufficient consents to amend the indenture.

Under $\S 14(\mathrm{e})$, the SEC has promulgated rules that do apply to debt tender offers. The most important of these is Rule 14e-1, which requires that a tender offer be kept open for a minimum period of twenty business days ${ }^{174}$ and that there be a ten business day extension of the offer after any increase or decrease in the offered premium. ${ }^{175}$ Yet, the practical impact of this rule is limited because of the bidder's ability to manipulate the proration period. For example, if a bidder tenders (or makes an exchange offer) for eighty percent of the bonds, and announces a first come, first served acceptance rule, ${ }^{176}$ any sophisticated bondholder will recognize that if it waits until the last day (that is, the twentieth business day) to tender, it risks having all or most of its bonds returned (and they will then be subject to any adverse indenture amendment for which the bidder was simultaneously soliciting consents). In short, the twenty business day rule may become a practical nullity because those who wish to tender must do so within the shorter proration period. ${ }^{177}$

In this light, an obvious reform would be to extend the proration and withdrawal rules to apply to debt tender offers in order to preserve a twenty business day period for investment decisionmaking in a context that is easily as complicated as that of equity tender offers. Although we would favor such an extension of the proration and withdrawal rules, we doubt that such changes would have more than a marginal impact. Bondholders that can coordinate do not need to fear issuer manipulation of the proration rules, and partial bids are not generally an effective strategy for the is-

${ }^{173}$ See 17 CFR $\& 240.10 \mathrm{~b}-13$ (1991).

174 See Rule 14e-1(a), 17 CFR § 240.14e-1(a) (1991).

175 See Rule 14e-1(b), 17 CFR \& 240.14e-1(b) (1991).

176 Typically, this first come, first served period will begin only after the expiration of some earlier period (for example, 10 days) during which bonds will be prorated if the offer is oversubscribed during that period. The effect is to truncate the 20 business day period into this shorter proration period. It was exactly this consequence that led the SEC to adopt Rule 14d-8 that extended proration for the life of the tender offer.

${ }^{177}$ Of course, if the bondholders can agree among themselves on a collective action strategy they cannot be pressured in this fashion. 
suer because it typically needs to acquire ninety to ninety-five percent of the bonds in order to realize the benefits of the recapitalization. ${ }^{178}$ The fear of proration will not stampede those with the stomach to hold out.

What steps could the SEC take that would make sense? We recommend a revision to an existing rule and two new rules. First, Rule $10 \mathrm{~b}-13$ should be revised so that it applies to debt securities as well as to equity securities. ${ }^{179}$ At a stroke, this reform would limit the ability of the issuer to offer side deals or higher prices to those threatening to hold out or to exercise their "blocking" position to veto the proposed indenture amendment. Thus, it would help to assure equality of treatment and to reduce the incentive for holdouts to seek a disproportionate share of the issuer's assets. Although we see no legal obstacle to the Commission's adoption of such a revised rule, ${ }^{180}$ its utility may be limited because of one obvious means for its evasion: the issuer can still pay more to the holdout after the exchange offer is completed. Still, courts have "integrated" post-tender offer payments with the tender offer in related contexts, ${ }^{181}$ and the SEC could issue an interpretive release codifying and extending this doctrine so that payments made within a certain period after the exchange offer would also be within the scope of Rule $10 \mathrm{~b}-13$, as amended.

Our second proposed rule would effectively structure combined exchange offers and exit consent solicitations so that they satisfied the requirements of our Form Three Offer. Indeed, such a proposed rule has already been submitted to the SEC by a coalition of sophisticated institutional investors. In late 1990, FMR Corp., the parent company in the Fidelity Mutual Fund family, and The Prudential Insurance Company of America jointly filed a

178 See notes 23-26 and accompanying text.

178 Rule 10b-13 provides that "[n]o person who makes a cash tender offer or exchange offer for any equity security shall, directly or indirectly, purchase ... any such security ...., otherwise than pursuant to such tender offer or exchange offer, from the time such tender offer or exchange offer is publicly announced or otherwise made known by such person to holders of the security to be acquired until the expiration of the [offer] ...." See 17 CFR § 240.10b-13 (1991).

${ }^{180}$ Unlike § 14(d) of the Williams Act, § 10(b) of the Securities Exchange Act of 1934 applies to all securities, including debt securities. See In re Washington Public Power Supply System Securities Litigation, 623 F Supp 1466 (W D Wash 1985).

${ }_{102}$ See Field v Trump, 850 F2d 938 (2d Cir 1988) (holding that the "best price" provision of $\$ 14(d)(7)$ of the Williams Act was violated where premium was paid to one party after purported "withdrawal" of tender offer). See also City Nat'l Bank v American Commonwealth Fin. Corp., 801 F2d 714 (4th Cir 1986) (Rule 10b-13 violated where shares were paid for during pendency of tender offer, even though agreement to purchase occurred prior thereto). 
rule-making petition with the SEC seeking a revision of Rule $14 \mathrm{e}-1$ that would preclude any solicitation of consents or proxies during a tender offer unless the offer "remains open until the expiration of ten business days after the results of the concluded solicitation of approval have been publicly disclosed." ${ }^{182}$ In short, these institutional investors wanted the right to vote before they tender-in effect, so that they could decide to tender if they failed in an earlier attempt to defeat the consent solicitation. As discussed earlier, we think this is the correct solution to the problem of coercion because it allows costless resistance but also permits the majority of the bondholders to discipline holdouts. The fact that sophisticated institutional investors that are not known for seeking additional governmental regulation have proposed it increases our sense that a market intervention is appropriate to this extent.

Finally, our third proposed rule would address the problem of vote buying. We recognize that courts have not barred vote buying in the case of bondholders (even though it is generally forbidden with respect to stock). ${ }^{183}$ We also understand that a variety of distinctions can be made between bondholders and stockholders that may make vote buying acceptable in the former case but not in the latter. ${ }^{184}$ Still, these distinctions are not relevant to the legal rule that we think should preclude vote buying in the context of the tender offer/exit consent solicitation: the SEC's "best price"

${ }_{182}$ See letter dated November 16, 1990, from Robert C. Pozen, General Counsel, FMR Corp., to Jonathan G. Katz, Secretary, United States Securities \& Exchange Commission (on file with U Chi L Rev). Eight other institutions, including several major insurance companies, joined in the petition.

${ }^{183}$ For a case upholding vote buying in the bondholder context, see Kass, CA Nos 8700 , 8701,8711 . Because no fiduciary duty exists between the corporation and its bondholders, vote buying by the issuer from bondholders does not breach any duty of trust. However, in Kass, the court did suggest that payments selectively made to some bondholders but not available to all might breach an implied covenant of good faith.

In the case of stock, vote buying has been historically prohibited both on statutory and fiduciary grounds. See NY Bus Corp L \$ 609(e) (McKinney 1991); Chew v Inverness Management Corp., 352 A2d 426, 429-30 (Del Chanc 1975). For the modern Delaware test, see Schreiber v Carney, 447 A2d 17 (Del Chanc 1982).

${ }^{184}$ For example, it can be argued that the bondholders' rights and expectations are limited to those created by contract, while shareholders may rely on a broader fiduciary right. The general objection to vote buying in the political sphere is that it may encourage corruption or at least the derogation of a civil duty. Given the bondholders' very narrow entitlements, this potential for pervasive corruption or moral erosion seems less plausible. Chancellor Allen reviewed these and other distinctions in Kass, CA Nos 8700, 8701, 8711, and found the analogy between the political duties of citizenship and the bondholders' position unpersuasive. 
rule. ${ }^{185}$ Essentially, a bondholder that votes against the proposed indenture amendment receives a lesser total payment for its bonds than does a bondholder that receives the consent fee. When otherwise identical securities receive different prices in the same tender or exchange offer, the "best price" rule should be seen as violated. Obviously, this argument requires that the payment for the exit consent be integrated with the tender price in order to reach the conclusion that the "best price" rule has been violated. Clearly, the two transactions are integrally related, and at least one SEC "no action" letter has integrated a contemporaneous payment for proxy consents with a tender offer and deemed the former part of the tender offer. ${ }^{186}$ Under our proposed interpretation, it would become impossible to pay exit consent fees if the consent solicitation was occurring during the pendency of a tender offer. With this restriction and the use of a Form Three Offer, we do not believe bondholder choice can be distorted by coercive exchange offers.

Still, the issue of SEC authority remains. Can the SEC extend the $\S 14(\mathrm{~d})$ rules to apply to debt securities by relying on $\S 14(\mathrm{e})$ ? In fact, at the time the SEC adopted Rule 14d-10, it partly relied upon $\S 14(\mathrm{e})$ for its authority. ${ }^{187}$ Because $\S 14(\mathrm{e})$ does apply to debt tender offers, the authority it provided for Rule $14 \mathrm{~d}-10$ suggests that the rule can be expanded to cover debt offers as well. ${ }^{188}$

The problem with this interpretation, however, is that the Supreme Court's decision in Schreiber $v$ Burlington Northern, Inc. ${ }^{188}$ implies that the SEC is empowered under $\S 14(\mathrm{e})$ to adopt only disclosure requirements, not substantive rules. ${ }^{190}$ In short, $\S$

185 Rule $14 d-10(a)(2)$ sets forth this rule. See note 172 . The "best price" rule is in turn based on $\S 14(d)(7)$. Unlike $\S 14(d)(6)$, which speaks of "equity securities," $\S 14(d)(7)$ makes no reference to equity securities, but simply requires that the "increased consideration" be paid "to each security holder whose securities are taken up . . . " 17 CFR \& 240.14(d) (1991).

186 See Playtex, 1988 SEC No-Act LEXIS at *11. This no-action letter was in the context of a different rule (Rule 14e-1(b), 17 CFR $\S 240.14$ ), but the issue of integration is identical.

187 See Amendments to Tender Offer Rules-All-Holders and Best-Price, 1986 SEC LEXIS 1179, *20 (Jul 11) ("While not essential to the adoption of the Rules, Section 14(e) of the Exchange Act provides additional authority to adopt these rules.").

${ }^{188}$ In Polaroid Corp. v Disney, 862 F2d 987, 995-96 (3d Cir 1988), the validity of Rule 14d-10 was upheld against an attack that it exceeded the SEC's authority. However, the court principally relied on the proration provision in $\S 14(\mathrm{~d})(6)$ as justifying the rule, and this provision does not apply to debt offers.

140 472 US $1,11-12$ (1985).

${ }^{100}$ But see Finnegan v Campeau Corp., 915 F2d 824, 831 (2d Cir 1990):

Finnegan asserts that the SEC is . . only empowered to regulate in the area of disclosure. This assertion misperceives the scope of the federal agency's power . . . The SEC is able to regulate agreements between bidders by virtue of its authority to define 
14(e) does not prohibit manipulative conduct "unless there has been some element of deception through a material misrepresentation or omission." 191 Such a narrow reading of $\S 14(\mathrm{e})$ is certainly possible, but it ignores that the rules adopted to date by the SEC have often had only a tangential relationship to disclosure. ${ }^{192}$ In this light, we believe that any SEC effort to generalize the "best price" rule by extending it to debt tender offers stands on at least as firm a foundation as the twenty business day rule and should be upheld if challenged. ${ }^{193}$ Indeed, a special feature of the rule proposed by Fidelity and Prudential is that it reads simply as a timing rule-one that gives securityholders additional time (ten business days) to decide after the results of the solicitation have been publicly announced. ${ }^{184}$ This is effectively indistinguishable from the rationale for the twenty business day rule.

At present, the SEC does not seem inclined to move in the direction we propose, but has instead informally adopted a new policy that has the indirect effect of discouraging consent solicitations that seek to strip the protective covenants from the indenture. The SEC's staff now takes the position that when significant covenants are eliminated by a bondholder vote, the effect is to exchange new securities for old, even though the bondholder rejects the exchange offer. ${ }^{195}$ In short, the issuer is substituting a new security free of covenants for the old bond with protective covenants. As a result, the issuer must either register the new bonds under the Securities Act of 1933 or find an exemption from registration. One

fraudulent, deceptive or manipulative practices and to prescribe means to prevent such practices. 15 USC \& 78(n)(e). Through its power to prohibit fraudulent activity, the SEC has supervisory authority over the submission of joint bids or other agreements in the corporate auction contest.

If Finnegan is correct in this statement that the SEC can regulate under $\S 14(\mathrm{e})$ matters only tangentially related to disclosure, then Rule $14 \mathrm{~d}-10$ can easily be extended to debt tender offers.

191 Polaroid, 862 F2d at 994.

102 For example, Rule 14e-1(a) requires a bidder to hold a tender offer open for a minimum period of 20 business days. See Rule 14e-1(a), 17 CFR $\S 240.14 e-1$ (a) (1991). Indeed, none of the rules set forth in subsections (a) through (d) of Rule 14e-1 relates to disclosure.

${ }^{193}$ We also consider it relevant that § $14(\mathrm{~d})(7)$ of the Williams Act, 15 USC \& 78n(d)(7) (1982), which is the statutory foundation of the "best price" rule, specifically refers to "security holders whose securities are taken up and paid for pursuant to the tender offer" and does not use the term "equity securities" (as § 14(d)(6), which deals with proration rights, does). The implication here is that $\S 14(\mathrm{~d})(7)$ has a broader scope than simply equity securities.

${ }^{194}$ See note 182 and accompanying text.

${ }^{105}$ See George A. Greenslade, SEC and Consent Solicitations of Debentureholders, NY L J 1 (Jul 5, 1991); Case and Harwood, Current Issues in Prepackaged Chapter 11 Plans at 139 (cited in note 8). 
well-known exemption from registration in the Securities Act of 1933 applies to exchange offers, ${ }^{196}$ but it has a number of limitations that inhibit the issuer's ability to conduct an exchange offer under it. ${ }^{197}$ Although we are sympathetic to the SEC's goal, we believe we have proposed a cleaner, simpler approach that does not overregulate all debt exchange offers in order to preclude a few pernicious ones.

\section{Conclusion}

The coercive potential of debt exchange and tender offers is hard to judge, but easy to correct. Often, apparent coercion by management actually masks efforts by the bondholders to protect themselves against holdouts. Yet, the appropriate response to the holdout problem is a measured one: namely, the Form Three Offer in which the vote on the indenture amendments precedes and is independent of the offer, so that bondholders can both vote against the amendments and later accept the exchange if they are unsuccessful in their opposition. Such a procedure makes resistance effectively costless to the bondholders and thus enables them to discipline holdouts without subjecting themselves to the risk that management's tactics may penalize all the bondholders.

Ideally, private contracting could implement our proposed reform, but we are sufficiently realistic to recognize that the remedy we envision must have been discerned by practitioners, and yet it has not been adopted. Moreover, private contracting cannot protect the holders of outstanding bonds. Protection might also be achieved through judicial interpretation of indenture language presently in use, but no movement in this direction is apparent.

Hence, both to deal with the inertial forces that inhibit innovation in bond contracts and to provide a remedy for holders of

106 Section 3(a)(9) of the Securities Act of 1933 exempts from the registration requirements of that Act any security exchanged by the issuer with its existing holders exclusively, where no commission or other remuneration is paid or given directly for soliciting such exchange. See 15 USC \& 77(c)(a)(9) (1988).

${ }_{107}$ To use the $\S 3(\mathrm{a})(9)$ exemption, the issuer must comply with the following restrictions: (1) it must offer the new securities to be exchanged only to existing holders; (2) the new securities must be issued by same issuer, and not an affiliate or subsidiary; and (3) no compensation may be paid for soliciting acceptances of the exchange offer. While the issuer's employees may to a degree solicit or recommend acceptance of the offer, investment bankers, professional solicitors, or other agents may not be employed for this purpose.

Although this last restriction has been marginally relaxed in some recent SEC no-action letters, see Seaman Furniture Co., 1989 SEC No-Act LEXIS 1014 (Oct 10), it still represents a substantial barrier for many issuers. See Vlahakis, Deleveraging-A Search for Rules in a Financial Free-for-All at 485-88 (cited in note 6); Case and Howard, Current Issues in Prepackaged Chapter 11 Plans at 36-38 (cited in note 8). 
outstanding debt securities, we propose two modest regulatory innovations: (1) an amendment of Rule $14 \mathrm{e}-1$ to ensure that the tender or exchange offer remains open for a sufficient period after the results of the vote or consent solicitation are announced, so that those who failed to block the amendment can tender on an equal footing;"198 and (2) an extension of the "best price" rule, Rule 14d-10, to apply to debt tender offers and to bar payments for votes during the course of the tender offer. ${ }^{199}$ Under the first rule, even if the corporate issuer made it a condition of its offer that all tenders of bonds had to be accompanied by an executed consent, it still would be possible for the bondholders that initially had opposed the consent solicitation to change their votes and tender with an executed consent once they learned that the solicitation had been successful. ${ }^{200} \mathrm{We}$ believe that, if vote buying were limited as we propose and the vote preceded the tender offer, bondholders would have an undistorted choice, and judicial review of the fairness of the transaction would not be necessary.

Recently, some commentators have optimistically foreseen "the privatization of bankruptcy" through out-of-court consensual reorganizations. ${ }^{201}$ Even if our proposed rules were adopted, we are somewhat less optimistic about the pace of progress toward such a happy conclusion. As noted earlier, vulture funds can sometimes resist indenture amendments and hold out even when their debt is subordinated to the new class issued in exchange for it. Thus, the prepackaged bankruptcy has distinct advantages because (1) two-

${ }^{108}$ See note 182 and accompanying text.

199 See notes $183-88$ and accompanying text.

${ }^{200}$ It would be clearer and simpler just to prohibit the use of a tender condition that the bonds be accompanied by an executed consent. Then, the issuer could still condition its offer on a favorable vote on its proposed indenture amendments, but it could not discriminate between bondholders that voted for or against it. However, we doubt that $\$ 14(\mathrm{e})$ of the Williams Act authorizes a prophylactic rule against specified tender offer conditions. See notes 188-94 and accompanying text. In contrast, Rule 14e-1 has long specified time limits, and we here propose only to add another such limit (namely, requiring the tender offer to continue for some reasonable period after the end of the consent solicitation and the announcement of the vote).

Corporate issuers could still frustrate our proposal by using a very short proration period, which would require the bondholder to tender before the vote was concluded. This could also be addressed under an addition to Rule $14 \mathrm{e}-1$, but we do not see partial tender offers as a realistic problem in this area where the issuer cannot afford to leave any substantial number of the existing class of bonds outstanding. Put simply, partial bids aggravate, rather than solve, the holdout problem for the issuer.

${ }^{201}$ See Michael C. Jensen, Active Investors, LBOs, and the Privatization of Bankruptcy, 2 Continental Bank J Applied Corp Fin 35, 41-44 (No 1, Spring 1989). 
thirds of the bonds can vote to effect a mandatory reclassification, (2) all members of the class must be treated equally, and (3) holding out is not legally possible. Yet, such a procedure entails the risk of high bankruptcy costs. Hence, there is a plausible case, first made by Professor Roe, ${ }^{202}$ for permitting bondholders to amend the indenture so as to reduce the principal and interest rate or extend the maturity in a manner currently forbidden by the Trust Indenture Act. ${ }^{203}$ In effect, such deregulation would permit out-ofcourt settlements to achieve the same mandatory reclassification of the debt securities as the bankruptcy court alone can currently accomplish. Although such an altered set of legal rules would clearly solve the holdout problem, the potential for coercion would be even greater in this context, and thus rules paralleling our proposed restrictions on vote buying seem all the more important.

Although we doubt that the "privatization of bankruptcy" will come without legislative action to expand bondholder capacity to amend the indenture and thus bind holdouts, we also believe that "privatization" should not come without reforms (whether legislative or administrative) to give bondholders an unconstrained choice. We believe we have proposed in this Article the simplest, least intrusive means to this end.

${ }^{202}$ See Roe, 97 Yale L J 232 (cited in note 24).

${ }^{208}$ See note 54 and accompanying text. 
